\title{
Article \\ Numerical Parametric Studies on the Stress Distribution in Rocks around Underground Silo
}

\author{
Sun-Hoon Kim ${ }^{1, *(1)}$ and Kwang-Jin Kim ${ }^{2}$ \\ 1 Department of Civil and Environmental Engineering, U1 University, Chungbuk 29131, Korea \\ 2 COMTEC RESEARCH, Seocho-ku, Seoul 06650, Korea; info@comtecresearch.co.kr \\ * Correspondence: kimsh@yd.ac.kr
}

Citation: Kim, S.-H.; Kim, K.-J.

Numerical Parametric Studies on the Stress Distribution in Rocks around Underground Silo. Appl. Sci. 2022, 12, 1613. https://doi.org/10.3390 /app12031613

Academic Editor: Haizhu Wang

Received: 24 December 2021

Accepted: 2 February 2022

Published: 3 February 2022

Publisher's Note: MDPI stays neutral with regard to jurisdictional claims in published maps and institutional affiliations.

Copyright: () 2022 by the authors Licensee MDPI, Basel, Switzerland. This article is an open access article distributed under the terms and conditions of the Creative Commons Attribution (CC BY) license (https:// creativecommons.org/licenses/by/ $4.0 /)$.

\begin{abstract}
The underground silo was constructed as a facility for the disposal of low- and intermediatelevel radioactive waste. It is divided into three parts: the upper-dome core, the lower-dome core, and the cylindrical-space core. Numerical parametric studies on the stress distribution occurring in the surrounding rocks around the underground silo are presented in this paper. It is assumed that the soil layer was distributed to a depth of $-4.3 \mathrm{~m}$ from the ground level, the weathered rocks were distributed to a depth of $-9.5 \mathrm{~m}$ from the bottom of the soil layer, and the rocks were distributed in the lower part of the weathered rocks. A 2D axial symmetric finite element model was considered for the numerical analysis of the underground silo. A 3D finite element model was used to verify the reliability of the 2D axial symmetric model. Finite element analysis was carried out under various ratios of in situ horizontal stress to vertical stress (Ko). The numerical results obtained through these analyses include detailed stress states in the $\mathrm{p}-\mathrm{q}$ and octahedral planes at key locations of finite element models around an underground silo. Contours of safety factor distributions are also presented to evaluate the overall structural safety of the surrounding rock mass, which is the main supporting body of the underground silo.
\end{abstract}

Keywords: underground silo; finite element; triaxial compression mode; triaxial extension mode; Lode angle; safety factor

\section{Introduction}

In Korea, the Wolsong Low and Intermediate Level Radioactive Waste Disposal Center (WLDC) at Gyeongju in North Gyeongsang province has a plan to construct a facility with a total capacity of 800,000 drums. The WLDC site is located in the southeast of the Korean Peninsula (see Figure 1) [1]. The first phase of the facility, an underground silo for the disposal of low- and intermediate-level radioactive waste (LILW) with a capacity of 100,000 drums, was completed in 2014 (see Figure 2) [2-4]. Low-level radioactive waste mainly consists of items such as filters, work clothes, gloves, and replacement parts for devices used routinely in nuclear power plants. Intermediate-level radioactive waste includes radioisotope (RI) waste generated by hospitals, industries, and research institutes. Lowand intermediate-level radioactive waste must be managed safely and according to strict protocols for a certain period of time in accordance with government regulations and guidelines. Such waste is permanently disposed of in the WLDC. 


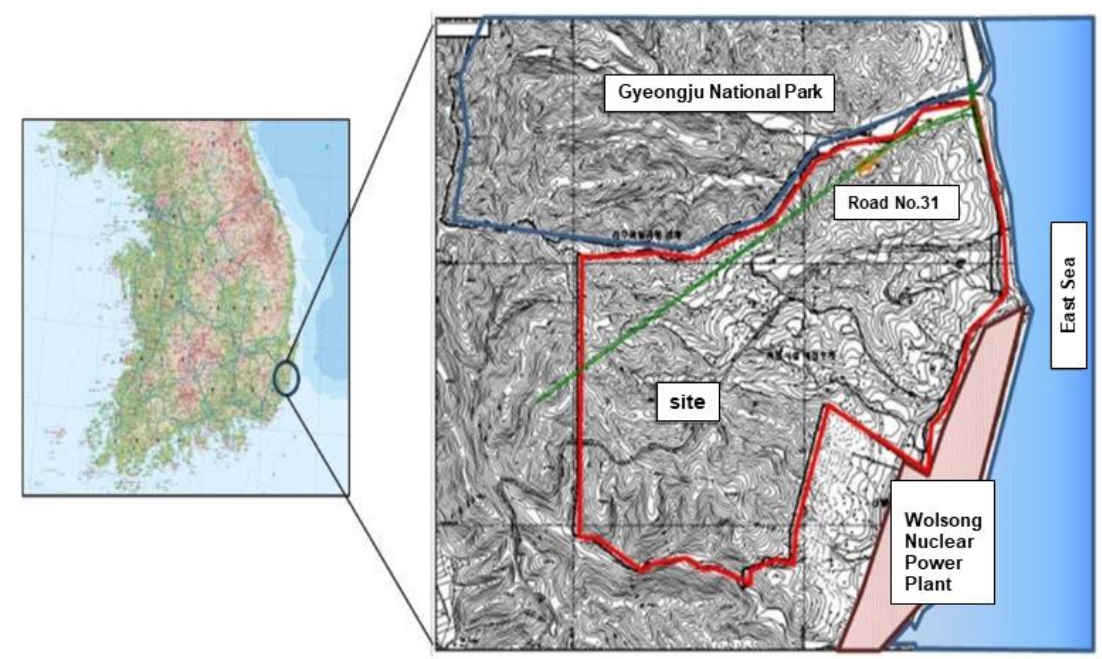

Figure 1. Location of the WLDC site in Korea.

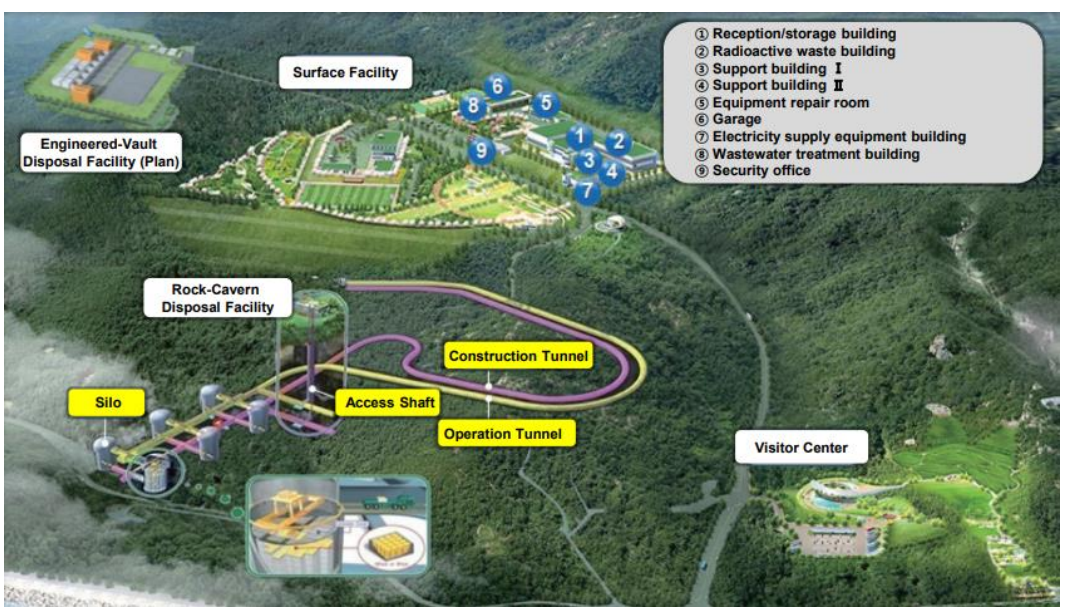

Figure 2. Layout of LILW disposal facilities.

It is essential to conduct a safety evaluation that comprehensively considers various types of impact on sites under construction or on the operation of nuclear facilities such as nuclear power plants, low- and intermediate-level radioactive waste disposal facilities, and spent fuel storage [5-8]. The Wolsong LILW facility's first phase was constructed $130 \mathrm{~m}$ below sea level, and consists of six silos, $50 \mathrm{~m}$ in height and $23.6 \mathrm{~m}$ in diameter (see Figure 3) [3,9]. Many studies have been carried out and published to verify its safety assessment since the facility was completed $[9,10]$.

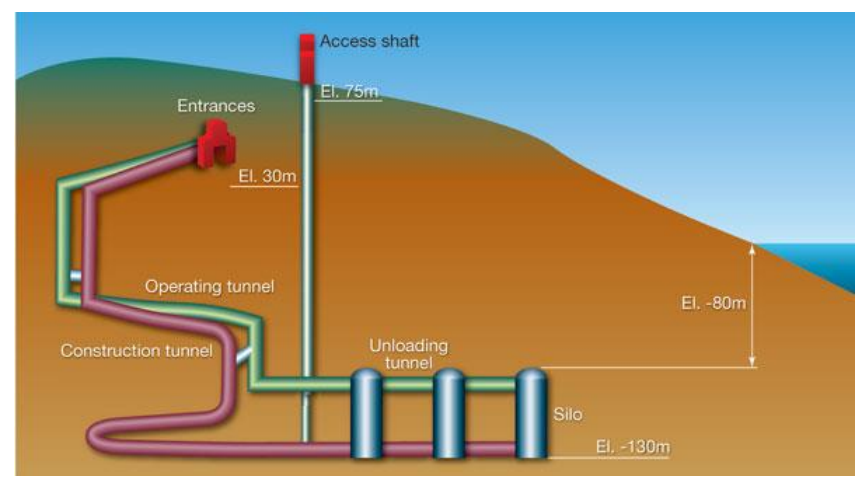

Figure 3. Side view of underground construction of LILW disposal facilities. 
Large-scale earthquakes occurred in 2016 and 2017 in Gyeongju and Pohang, respectively. Both arears are near the WLDC, and interest in the stability of the underground silo increased significantly [11,12]. However, unfortunately, there has been little research on the stress distribution in the rocks around the underground silos used as LILW disposal facilities [13].

Therefore, this paper presents numerical parametric studies on the stress distribution occurring in the surrounding rock mass around an underground silo which was constructed as a facility for the disposal of low- and intermediate-level radioactive waste. The 2D axial symmetric finite element model was used. The 3D finite element model was also used to verify the reliability of the 2D axial symmetric model. Finite element analyses of the underground silo were performed under various changes in the value of Ko, and the numerical results obtained through these analyses were also examined.

\section{The Underground Silo}

\subsection{Layout of the Underground Silo}

A conceptual drawing of the underground silo is presented in Figure 4 [1,14]. Its engineering barrier system is composed of a concrete silo, waste packages, disposal containers, and backfill. The walls of the silo are circular and the roof is in the form of a dome. The inside diameter is $23.6 \mathrm{~m}$ and the height of the wall is $35 \mathrm{~m}$. The silo dome's diameter is $30 \mathrm{~m}$ and its height is $17.4 \mathrm{~m}$. The upper part of the underground silos is located at $-80 \mathrm{~m}$ below sea level, and the lower part is located at $-130 \mathrm{~m}$ below sea level.

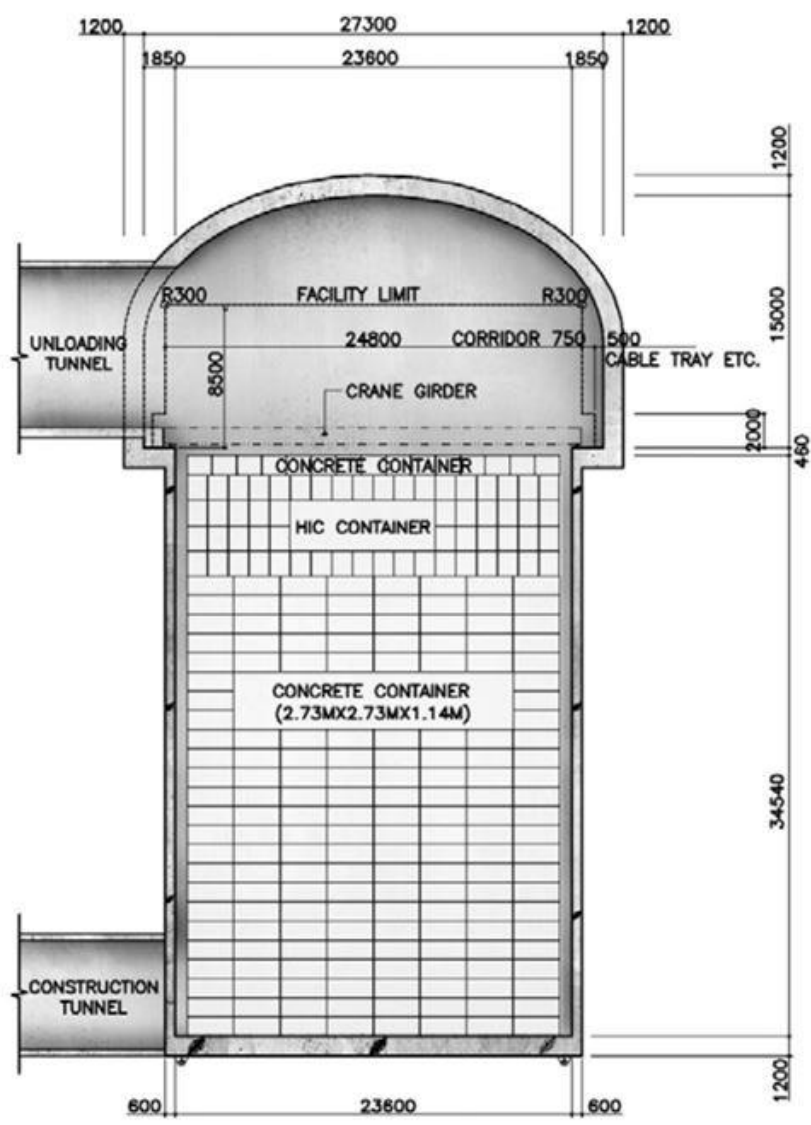

Figure 4. Drawing and dimensions of underground silo (unit: $\mathrm{mm}$ ).

\subsection{In-Situ Stress State and Material Properties}

According to the results of a detailed geological survey of the site area with a radius of $1 \mathrm{~km}$ centered on the WLDC site in Wolsong, the geology of the WLDC site is mainly 
composed of tertiary plutonic rocks, cretaceous sedimentary rocks, and intrusive rocks (see Figure 5) [15,16]. More detailed geological survey data are described in [16].

It was reported in an investigation of the site's characteristics that the ratio of in situ horizontal stress to vertical stress (Ko) was approximately between 1.17 and 1.92 [17]. The numerical analysis presented here was therefore performed to predict the stress distribution occurring in rocks around the silo for three cases $(\mathrm{Ko}=0.5,1.0$ and 2.0). The soil layer was assumed to be $-4.3 \mathrm{~m}$ deep from ground level, and the weathering rock was assumed to be $-9.5 \mathrm{~m}$ deep, starting from the bottom of the soil layer. It was assumed that the rock was distributed from the lower part of the weathering rock to the deep layer. Typical values for the material properties of geomaterials used for this finite element modeling were assumed, as shown in Table 1 [13]. All geomaterials were assumed to be homogeneous and isotropic.

Table 1. Typical material properties of geomaterials.

\begin{tabular}{|c|c|c|c|c|c|}
\hline $\begin{array}{l}\text { Ground } \\
\text { Layer }\end{array}$ & $\begin{array}{c}\text { Unit } \\
\text { Weight } \\
\left(\mathrm{kN} / \mathrm{m}^{3}\right)\end{array}$ & $\begin{array}{l}\text { Young's } \\
\text { Modulus } \\
\text { (MPa) }\end{array}$ & $\begin{array}{c}\text { Poisson's } \\
\text { Ratio }\end{array}$ & $\begin{array}{c}\text { Internal Friction } \\
\text { Angle } \\
\text { (degree) }\end{array}$ & $\begin{array}{c}\text { Cohesion } \\
\text { (MPa) }\end{array}$ \\
\hline Soil layer & 18.56 & $0.124 \times 10^{4}$ & 0.33 & 30 & 0.35 \\
\hline $\begin{array}{l}\text { Weathering } \\
\text { rock }\end{array}$ & 20.52 & $0.342 \times 10^{4}$ & 0.30 & 38 & 2.08 \\
\hline Rock & 26.28 & $8.260 \times 10^{4}$ & 0.27 & 43 & 2.26 \\
\hline
\end{tabular}

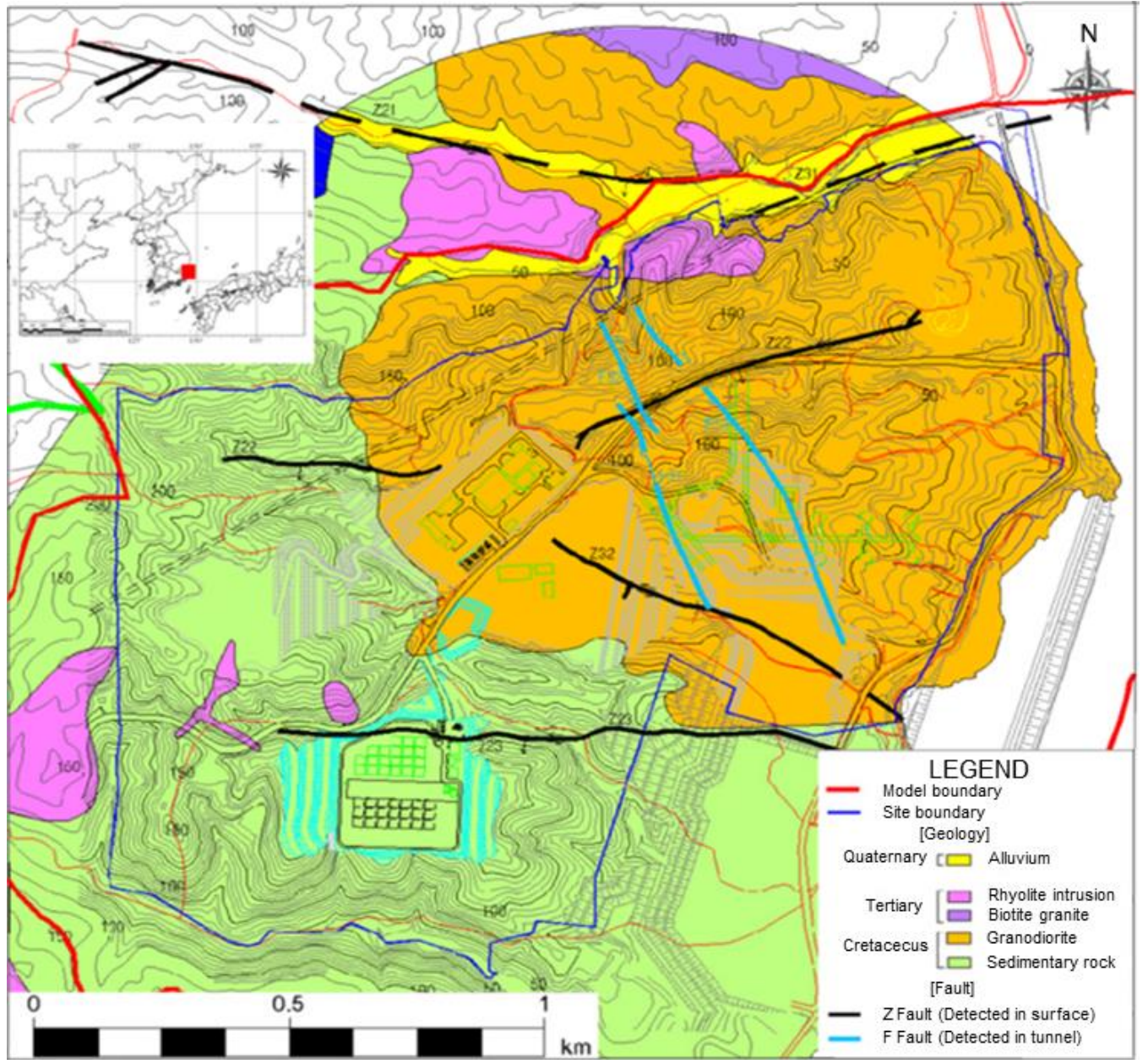

Figure 5. Geological map of the Wolsong site. 


\section{Theoretical Background}

\subsection{Material Model Description}

The Generalized Hoek and Brown Model [18-20] was applied to this numerical analysis. This model represents the constitutive relationship of rocks or soils. The failure surface is described in its generalized form by the following equation:

$$
\mathrm{F}(\mathrm{p}, \mathrm{q}, \theta)=\mathrm{q}-\left\{(\alpha+\beta \mathrm{p})^{\mathrm{n}}+\mathrm{k}\right\} \mathrm{R}(\theta)=0
$$

where the stress invariants $(\mathrm{p}, \mathrm{q}$, and $\theta)$ are defined in Appendix $A$ along with the expression for $\mathrm{R}(\theta)$.

The function $R(\theta)$ denotes the shape of the yield surface projected onto the octahedral plane. The effect of the change of parameter $k$ on the shape of the yield surface is shown in Figures 6 and 7 . The value $k$ denotes the ratio of the shear strength in the triaxial extension state to the shear strength in the triaxial compression state at the same mean pressure. It can vary from 0.5 to 1.0 and is a measure of the influence of the intermediate principal stress on the yield surface. When it is unity, $R(\theta)$ is circular, representing a von Mises or DruckerPrager failure model. When it is less than unity, $R(\theta)$ is a smooth cornered approximation to the Mohr-Coulomb failure envelope [21-23]. The parameter $n$ in Equation (1) determines the shape of the yield surface in the $\mathrm{p}-\mathrm{q}$ plane.

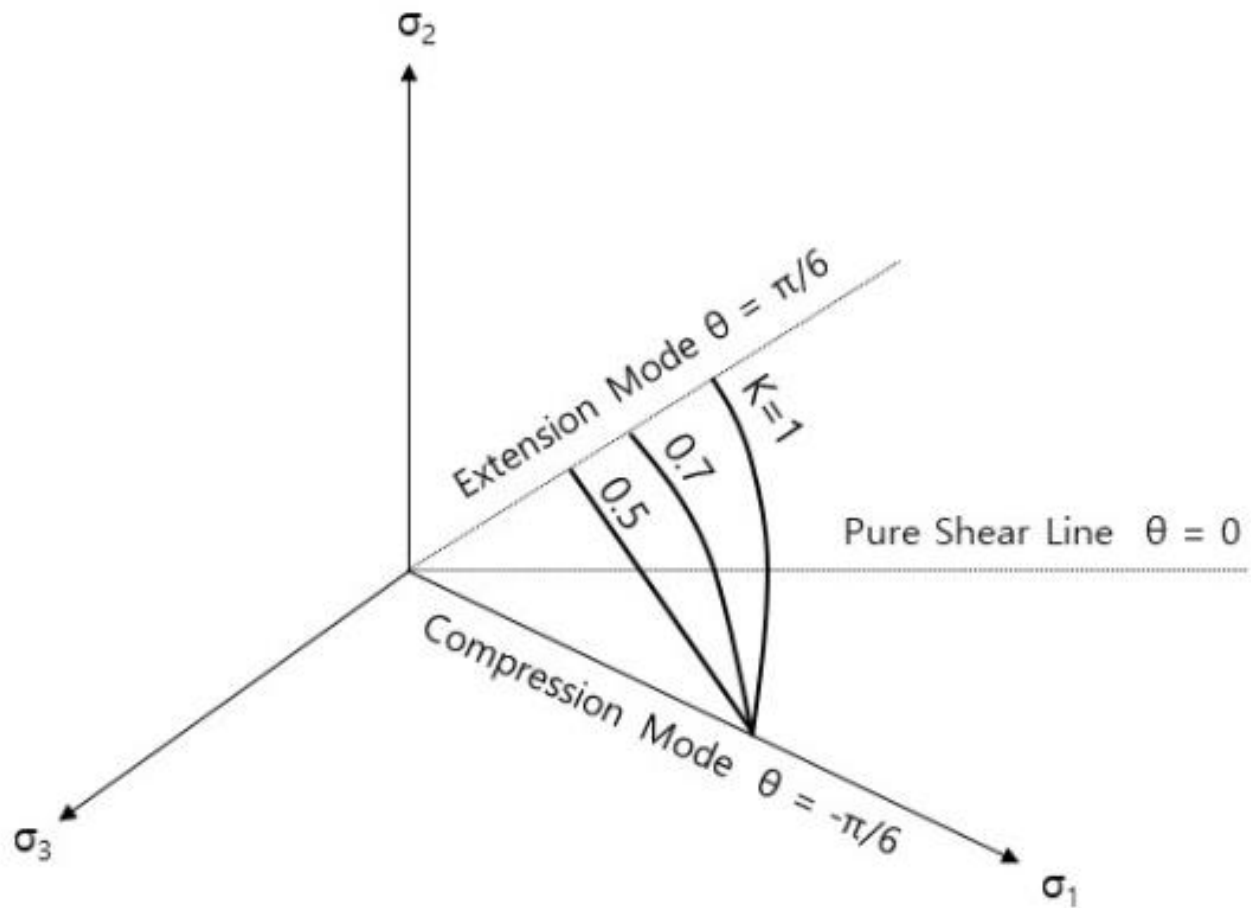

Figure 6. Triaxial compression and extension modes in an octahedral plane.

When $\mathrm{n}=0$, the strength envelope decreases to the von Mises or Tresca yield surface, and the shear strength shows a constant value for mean pressure. When $n=1 / 2$, the strength envelope represents a Hoek and Brown failure surface [22]. This nonlinear failure model means a multidimensional generalization of the original one-dimensional axial symmetric Hoek and Brown model, based on extensive laboratory experiments and field data [24]. When $\mathrm{n}=1$, the strength envelope in the $\mathrm{p}-\mathrm{q}$ plane is representative of the Drucker-Prager or Mohr-Coulomb failure surface and shear strength is linearly proportional to the mean pressure. 


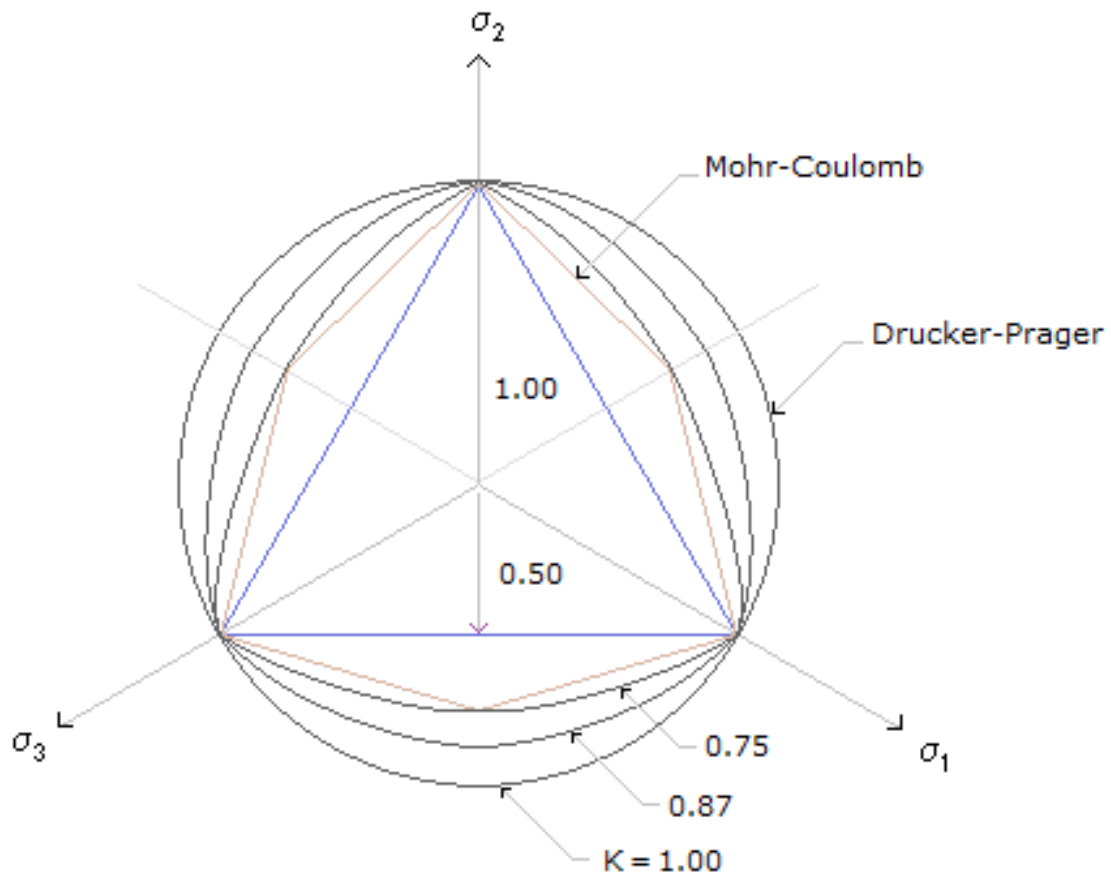

Figure 7. Shape of the strength envelope, $R(\theta)$, in an octahedral plane.

The parameters $\alpha, \beta$, and $\kappa$ of Equation (1) define the failure envelope in the $p-q$ plane as values determined in laboratory tests. Recommended relationships for determining these parameters for various types of materials are listed in Table 2 . The empirical material parameters for $n=1 / 2$ are tabulated in Table A1 in Appendix A for several different rock types, as descriptors of rock quality. A detailed description of rock quality is presented in Table A2 in Appendix A.

Table 2. Material constants in the Generalized Hoek and Brown Model.

$n=0$

$n=1 / 2$

$n=1$

von Mises or Tresca

Hoek and Brown

Mohr-Coulomb or Drucker-Prager

\begin{tabular}{|c|c|c|c|}
\hline$\alpha$ & $\mathrm{N} / \mathrm{A}$ & $\left(m^{2} / 36+s\right) \cdot \sigma_{c}^{2}$ & 1000 \\
\hline$\beta$ & $\mathrm{N} / \mathrm{A}$ & $\mathrm{m} \cdot \sigma_{\mathcal{c}}$ & $6 \sin \varnothing /(3-\sin \varnothing)$ \\
\hline K & $\mathrm{q}^{\prime}-1$ & $(1 / 6) \cdot\left(m \cdot \sigma_{c}\right)$ & {$[3(1-\sin \varnothing) /(3-\sin \varnothing)] \cdot \sigma_{c}-1000$} \\
\hline
\end{tabular}

The model includes the classical von Mises, Drucker-Prager, and Mohr-Coulomb failure equations, as well as the empirically based Hoek and Brown failure equation [25,26]. One of its useful features is that the model can use empirical data as a basis for modelling the strength of an in situ rock mass when the in situ strength data are not available. The three-dimensional elasto-plastic matrix for the Generalized Hoek and Brown Model is presented in Appendix A. The model assumes an elastic state below the failure surface, mutually dependent volumetric and deviatoric behavior once it reaches the failure surface, and a perfectly plastic state along the failure surface.

\subsection{Safety Factor}

The safety factor is defined by the ratio of the ultimate deviatoric stress to the current deviatoric stress at a given mean pressure, as illustrated in Figure 8. It should be noted that the ultimate deviatoric stress depends on not only the mean pressure but also on the Lode angle in the octahedral plane. The recommended content in the state range according to 
the safety factor is summarized in Table 3. The contour of the safety factor distributions provides valuable information for evaluating the structural safety of the surrounding rock, which is the main supporting body of the underground silo.

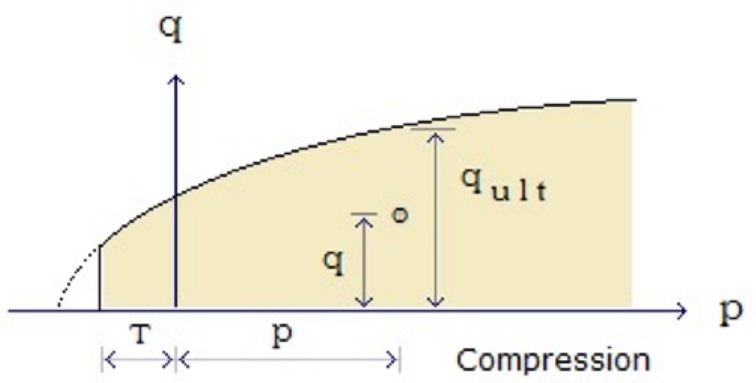

Factor of Safety (FS) is defined as:

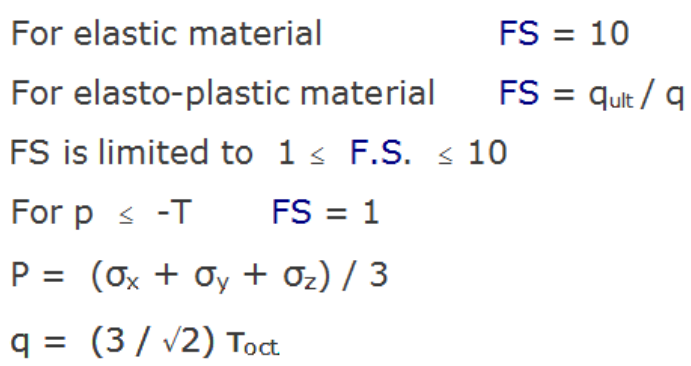

Figure 8. Definition of the safety factor.

Table 3. State range of the surrounding rock according to the safety factor.

\begin{tabular}{cc}
\hline Safety Factor (FS) & State of Surrouding Rock \\
\hline $\mathrm{FS}=1$ & Possibility of failure \\
\hline $1<\mathrm{FS} \leq 2$ & Safe but observation required \\
\hline $2<\mathrm{FS} \leq 10$ & Safe \\
\hline
\end{tabular}

\section{Finite Element Modeling}

There are many kinds of numerical method available to solve geomechanical problems that take into consideration the effect of nonlinearity $[27,28]$. In this study, finite element analysis [29-33] was used in the numerical modeling of the underground silo and the rock surrounding the underground silo.

One underground silo was examined in this finite element modeling procedure, although six underground silos have been constructed and are currently in operation at the Wolsong LILW disposal facility. The underground silo is divided into three parts: the upperdome core, the lower-dome core linked to the operating tunnel, and the cylindrical-space core linked to the construction tunnel and used for storing radioactive waste packages.

The size of the analysis domain for 2D axial symmetric finite element modeling was set from the ground-surface level to a depth of $250 \mathrm{~m}$ from the silo floor in the vertical plane, and up to $250 \mathrm{~m}$ - ten times the diameter of the silo wall-to the left and right in the horizontal plane. It was also set to a thickness of $250 \mathrm{~m}$ for 3D analysis. The underground silo was excavated in step-by-step stages when it was under construction. However, the effects of this multi-step excavation of the underground silo site were ignored, since it is located in the hardrock zone. Thus, for this numerical study, it is assumed that the underground silo was excavated in a single step.

A 3D analysis model was constructed to verify the 2D axial symmetric analysis model. The 3D finite element model of the analysis domain, which includes the underground silo 
and the surrounding geomaterials, is depicted in Figure 9. The numerical results of stress and displacement obtained from carrying out a finite element analysis of this model were examined and compared at key locations around the underground silo, as shown in Figure 10.
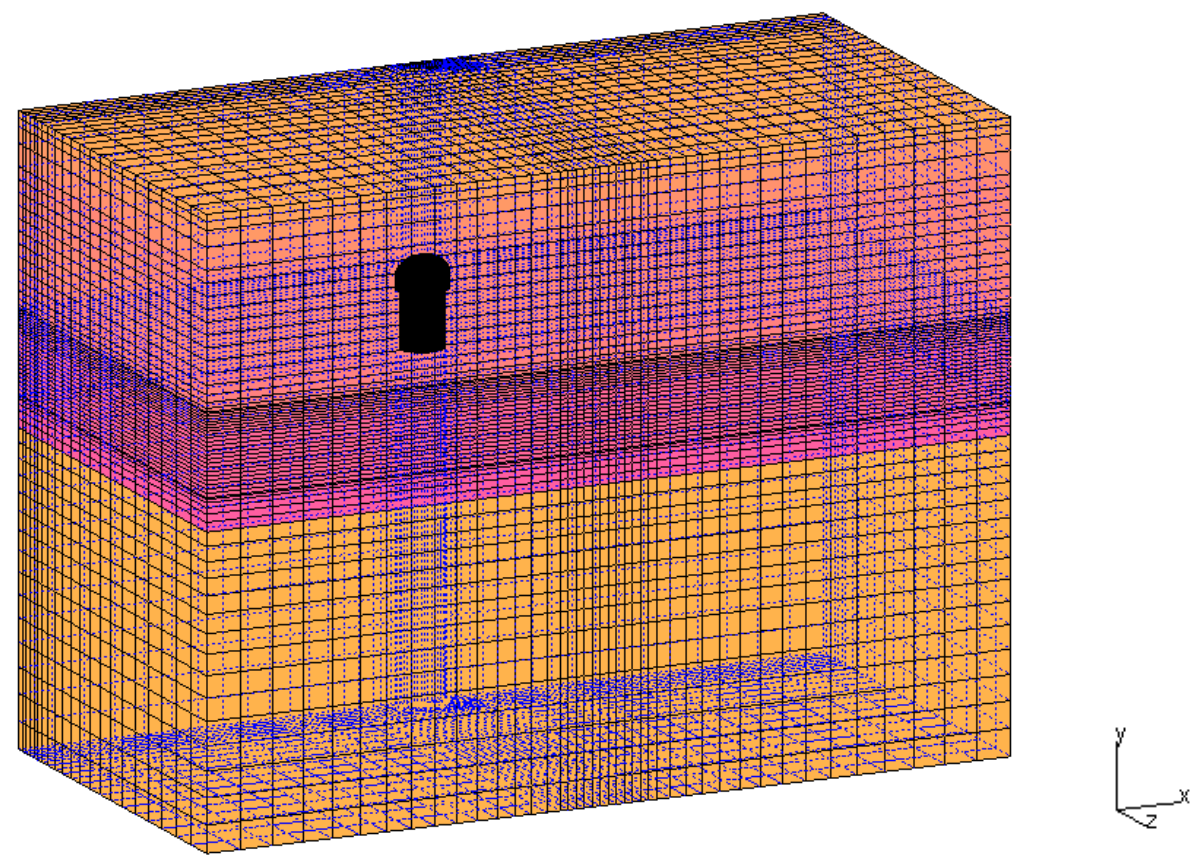

(a) Whole 3D finite element mesh

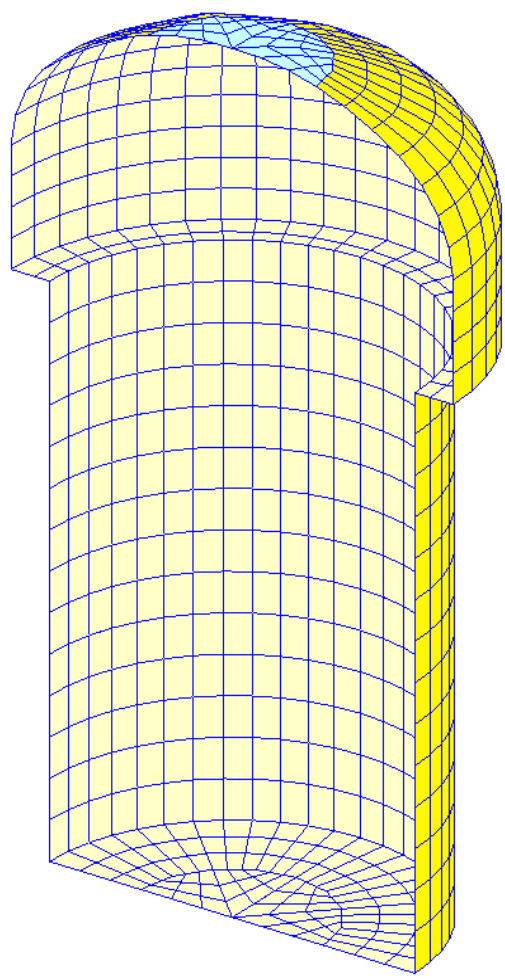

(b) Half of the 3D model of the silo

Figure 9. 3D finite element model of the underground silo. 


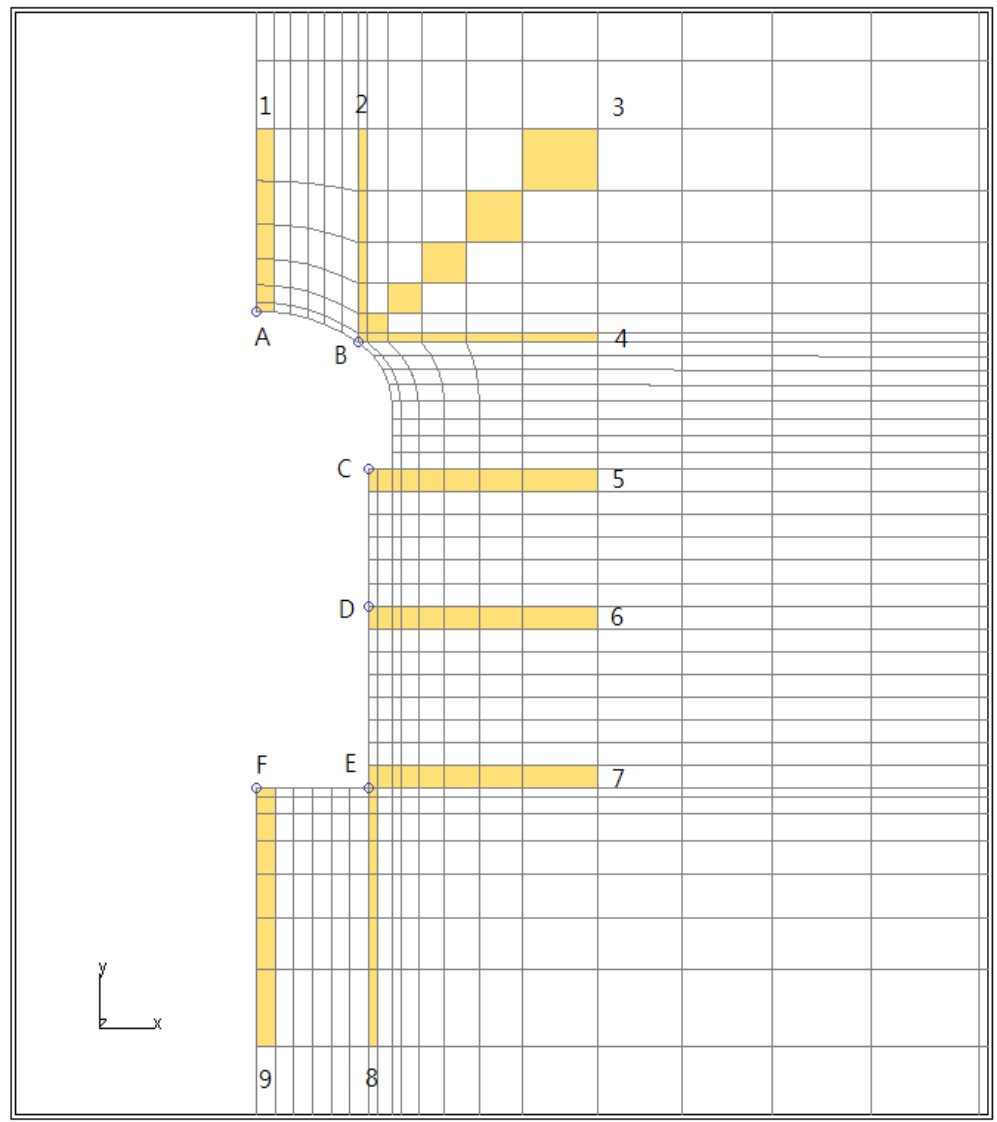

Figure 10. Key locations of the finite element model after excavation of the underground silo.

\section{Numerical Results}

\subsection{Displacements}

Exaggerated deformed shapes resulting from the excavation of the underground silo are shown in Figure 11 for three different cases of Ko values. For the case of Ko $=0.5$, the maximum displacement $(0.85 \mathrm{~mm})$ occurred in the vertical direction at the central point of the silo's bottom surface (Location F) since the in situ vertical stresses were twice as high as the in situ horizontal stresses. For the case of $\mathrm{Ko}=2.0$, on the other hand, the maximum displacement $(1.32 \mathrm{~mm})$ occurred in the radial direction at mid-point of the cylindrical wall (Location D) since the in situ horizontal stresses were twice as high as the in situ vertical stresses. For the case of $\mathrm{Ko}=1.0$, where the in-situ stresses were hydrostatic, the maximum vertical displacement $(0.786 \mathrm{~mm})$ at central point of the silo's bottom surface (Location F) were somewhat higher than the radial displacement $(0.652 \mathrm{~mm})$ at the mid-point of the cylindrical wall (Location D).

The displacements at key locations obtained through 2D axial symmetric analysis based on change in the ratio of in situ horizontal stress to vertical stress (Ko) are presented in Table 4. The displacements at key locations obtained through 3D analysis based on change in the ratio of in situ horizontal stress to vertical stress (Ko) are presented in Table 5. It can be seen that numerical results of the 3D analysis were almost identical everywhere to those of the 2D axial symmetric analysis. Therefore, the reliability of the 2D finite element model was confirmed. 


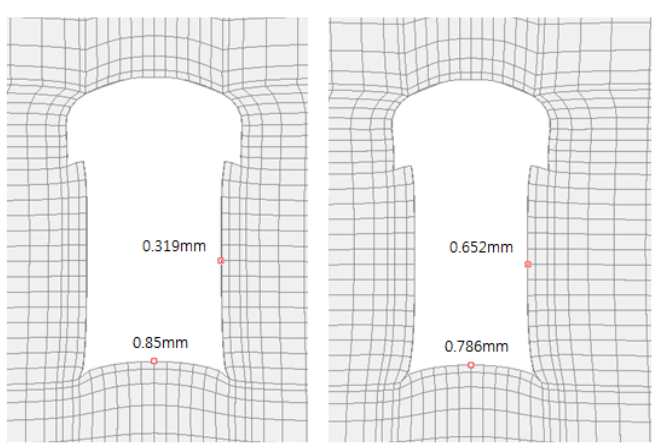

Note: Displacements are 5000 times magnified (b) $\mathrm{Ko}=1.0$

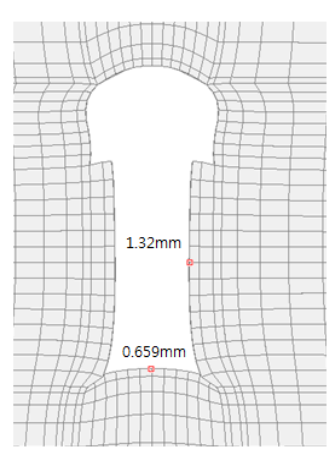

(c) $\mathrm{Ko}=2.0$

Figure 11. Deformed shapes of the underground silo.

Table 4. Displacements at key locations obtained through 2D analysis (unit: $\mathrm{mm}$ ).

\begin{tabular}{|c|c|c|c|c|}
\hline Locations & Direction & Ko $=0.5$ & $K o=1.0$ & $K o=2.0$ \\
\hline \multirow{2}{*}{ A } & Vertical & -0.485 & -0.375 & -0.153 \\
\hline & Radial & 0.0 & 0.0 & 0.0 \\
\hline \multirow{2}{*}{ B } & Vertical & -0.318 & -0.234 & -0.064 \\
\hline & Radial & -0.076 & -0.230 & -0.538 \\
\hline \multirow{2}{*}{ C } & Vertical & 0.284 & 0.284 & 0.283 \\
\hline & Radial & -0.208 & -0.540 & -1.205 \\
\hline \multirow{2}{*}{$\mathrm{D}$} & Vertical & 0.087 & 0.070 & 0.038 \\
\hline & Radial & -0.318 & -0.651 & $-1.316(\max )$ \\
\hline \multirow{2}{*}{$\mathrm{E}$} & Vertical & 0.281 & 0.206 & 0.055 \\
\hline & Radial & -0.067 & -0.191 & -0.438 \\
\hline \multirow{2}{*}{$\mathrm{F}$} & Vertical & 0.848 & 0.785 & 0.658 \\
\hline & Radial & 0.0 & 0.0 & 0.0 \\
\hline
\end{tabular}

Table 5. Displacements at key locations obtained through 3D analysis (unit: mm).

\begin{tabular}{ccccc}
\hline Locations & Direction & Ko $=\mathbf{0 . 5}$ & Ko $=\mathbf{1 . 0}$ & Ko $=\mathbf{2 . 0}$ \\
\hline \multirow{2}{*}{$\mathrm{A}$} & Vertical & -0.489 & -0.379 & -0.158 \\
\cline { 2 - 5 } & Radial & 0.0 & 0.0 & 0.0 \\
\hline \multirow{2}{*}{$\mathrm{B}$} & Vertical & -0.321 & -0.235 & -0.064 \\
\cline { 2 - 5 } & Radial & -0.078 & -0.234 & -0.547 \\
\hline \multirow{2}{*}{$\mathrm{C}$} & Vertical & 0.286 & 0.285 & 0.283 \\
\cline { 2 - 5 } & Radial & -0.209 & -0.542 & -1.208 \\
\hline \multirow{2}{*}{$\mathrm{D}$} & Vertical & 0.087 & 0.703 & 0.037 \\
\cline { 2 - 5 } & Radial & -0.319 & -0.652 & $-1.320(\mathrm{Max})$ \\
\hline \multirow{2}{*}{$\mathrm{E}$} & Vertical & 0.282 & 0.206 & 0.054 \\
\cline { 2 - 5 } & Radial & -0.067 & -0.191 & -0.439 \\
\hline \multirow{2}{*}{$\mathrm{F}$} & Vertical & $0.850(\mathrm{Max})$ & $0.786(\mathrm{Max})$ & 0.659 \\
\cline { 2 - 5 } & Radial & 0.0 & 0.0 & 0.0 \\
\hline
\end{tabular}




\subsection{Stresses}

This section presents the numerical results for stresses obtained by 2D axial symmetric analysis. The results of computed stresses examined at the key locations are presented in Figure 10. Nine different lines were selected around the silo: a vertical upward line, A1, above dome crown; a vertical upward line, B2; a diagonal line, B3; a horizontal line, B4; a horizontal line, $\mathrm{C} 5$, at the dome's bottom; a horizontal line, D6, at the middle of the storage wall; a horizontal line, E7; a vertical downward line, E8, at the silo's bottom corner; and a vertical downward line, F9, at the bottom center of the silo. Among all these locations, it was found that deviatoric stresses were most concentrated around two locations: $C$ and D. Therefore, in the following analysis, stress results will be interpreted along the two corresponding lines, $\mathrm{C} 5$ and D6.

In Figures 12-14, the stress state in the $\mathrm{p}-\mathrm{q}$ plane is summarized for Ko values of 0.5, 1.0, and 2.0, along with the strength envelopes corresponding to the triaxial compression and extension modes. Using the given material properties $(\varnothing=43$ and $\mathrm{c}=2.26 \mathrm{MPa}$, these two upper- and lower-bound strength envelopes were computed based on the following equations:

$$
\begin{gathered}
\mathrm{q}_{\mathrm{TXC}}=[6 \sin \varnothing /(3-\sin \varnothing)] \cdot \mathrm{P}+[6 \cos \varnothing /(3-\sin \varnothing)] \cdot \mathrm{c}=1.765 \mathrm{P}+4.27 \\
\mathrm{q}_{\mathrm{TXE}}=[(3-\sin \varnothing) /(3+\sin \varnothing)] \cdot \mathrm{q}_{\mathrm{TXC}}=0.63 \mathrm{q}_{\mathrm{TXC}}
\end{gathered}
$$

Generally, the deviatoric shear stresses increased with the distance from the storage wall, but the mean pressures remained more-or-less constant, except for the first three points along line $\mathrm{C} 5$ for $\mathrm{Ko}=0.5$.

For $\mathrm{Ko}=0.5$, all deviatoric stresses were somewhat below the lower-bound strength envelope in the triaxial extension mode. For $\mathrm{Ko}=1.0$, deviatoric stress in the first element in line $\mathrm{C} 5$ reached the lower-bound strength in the triaxial extension mode. For Ko $=2.0$, the deviatoric stresses in the first two elements in lines C5 and D6 were above the lower-bound strength envelope and the first element in line $\mathrm{C} 5$ almost reached the upper-bound shear strength in the triaxial compression mode.

The plots in the $p-q$ plane shown in Figures 11-13 provide a good evaluation of the stress states along lines C5 and D6 by comparing the upper- and lower-bound strength envelopes. However, these plots do not show the ultimate strength corresponding to each stress point since the ultimate strengths are dependent on both mean pressure and Lode angle, as explained in the material model in Section 3 [34,35]. Therefore, in order to evaluate more accurately, an additional plot showing the stress state in the octahedral plane is necessary.

The stress states in the $p-q$ and $t-q$ planes are summarized in Figures $15-17$ for Ko values of $0.5,1.0$ and 2.0 , respectively. The $t-q$ plane means a $\theta-q$ plane failure surface. The $\mathrm{t}-\mathrm{q}$ plot, as introduced in this study, is essentially the simpler form of deviatoric stress plot in the octahedral plane shown in Figures 6 and 7.

For $\mathrm{Ko}=0.5$, the stress state was somewhat close to the triaxial compression mode at Location C, but was closer still to the triaxial extension mode at Location D. The safety factors, as defined in Figure 17 in the next section, were 2.61 and 1.58 at Locations $C$ and D, respectively.

For Ko $=1.0$, the stress state was very close to the triaxial compression mode at Location C, but was very close to the deviatoric pure shear mode at Location D, with a Lode angel of $-1.9^{\circ}$. The safety factors were 1.47 and 1.34 at Locations $C$ and $D$, respectively.

For $\mathrm{Ko}=2.0$, the stress state at Location $\mathrm{C}$ was almost in the triaxial compression mode, reaching ultimate strength with a safety factor of 1.02. The stress state at Location $\mathrm{D}$ was also close to the triaxial compression mode, with a Lode angle of $-20.9^{\circ}$, reaching ultimate strength with a safety factor of 1.08. Thus, the silo's storage wall may be subjected to the onset of shear failure at these regions. 
Stress State $: \mathrm{Ko}=0.5$ Along Line C5

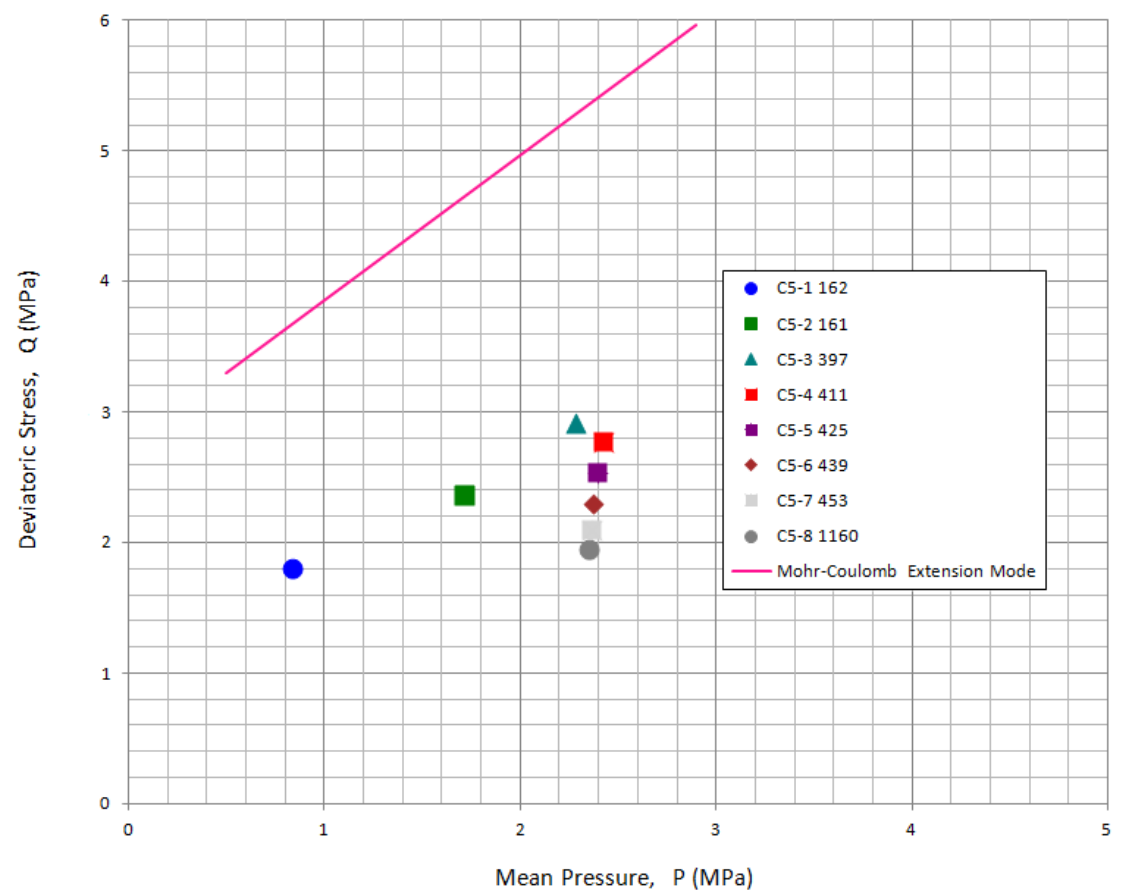

(a)

Stress State : Ko = 0.5 Along Line D6

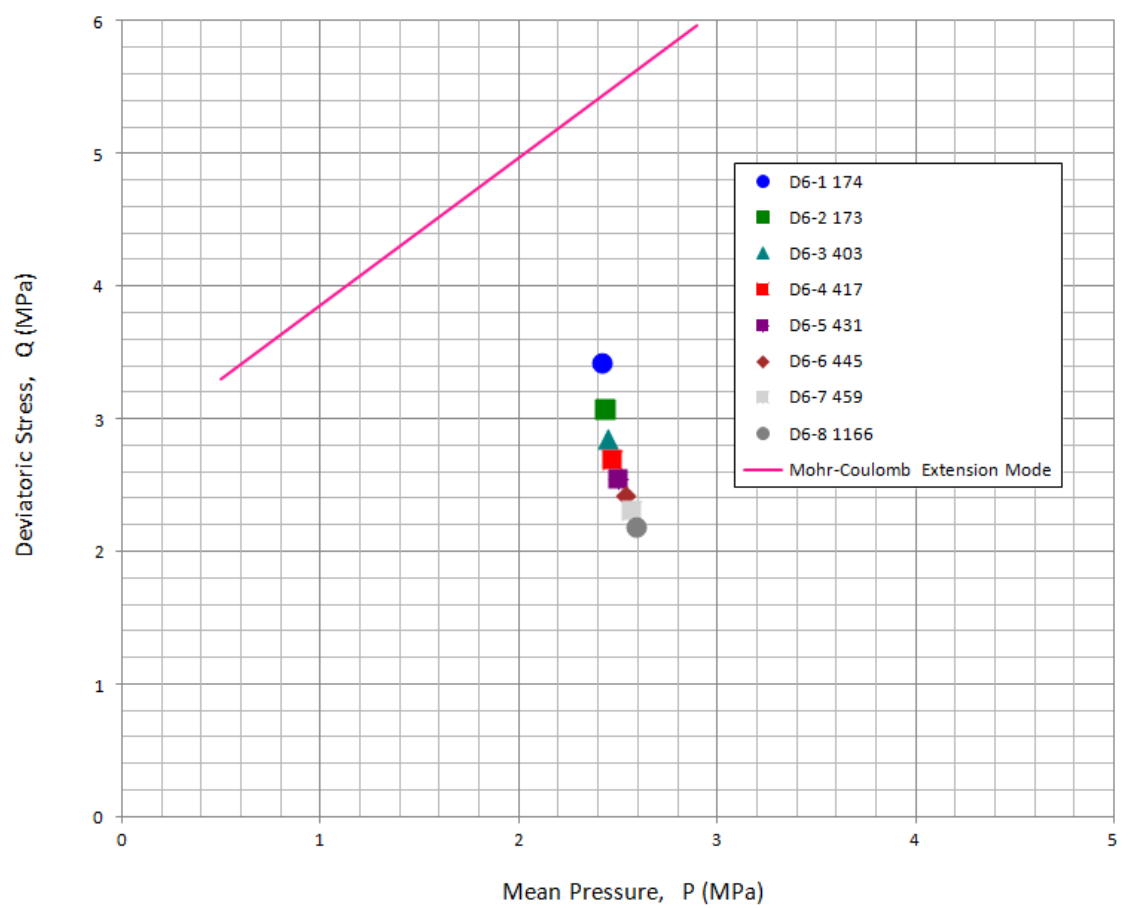

(b)

Figure 12. Stress state $(\mathrm{Ko}=0.5)$ : (a) Line C5; (b) Line D6. 
Stress State $:$ Ko $=1.0$ Along Line D6

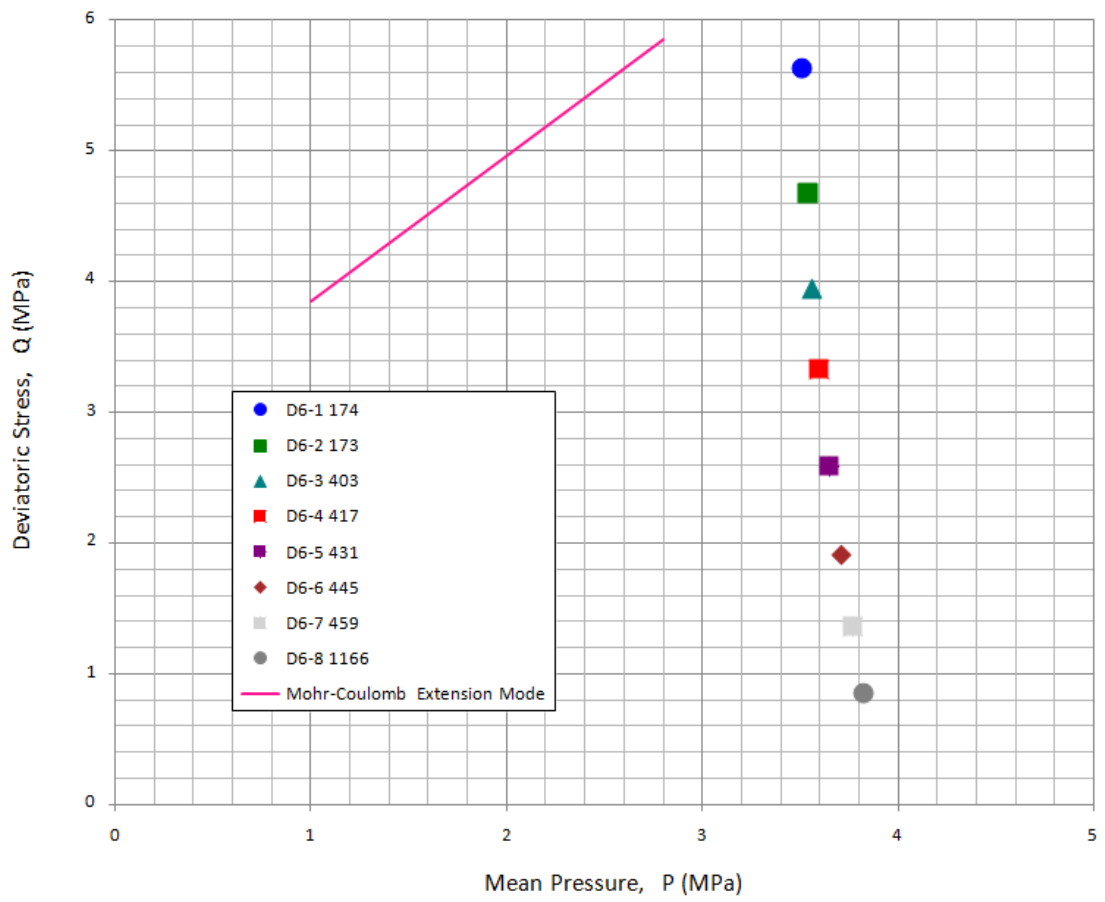

(a)

Stress State : Ko = 1.0 Along Line D6

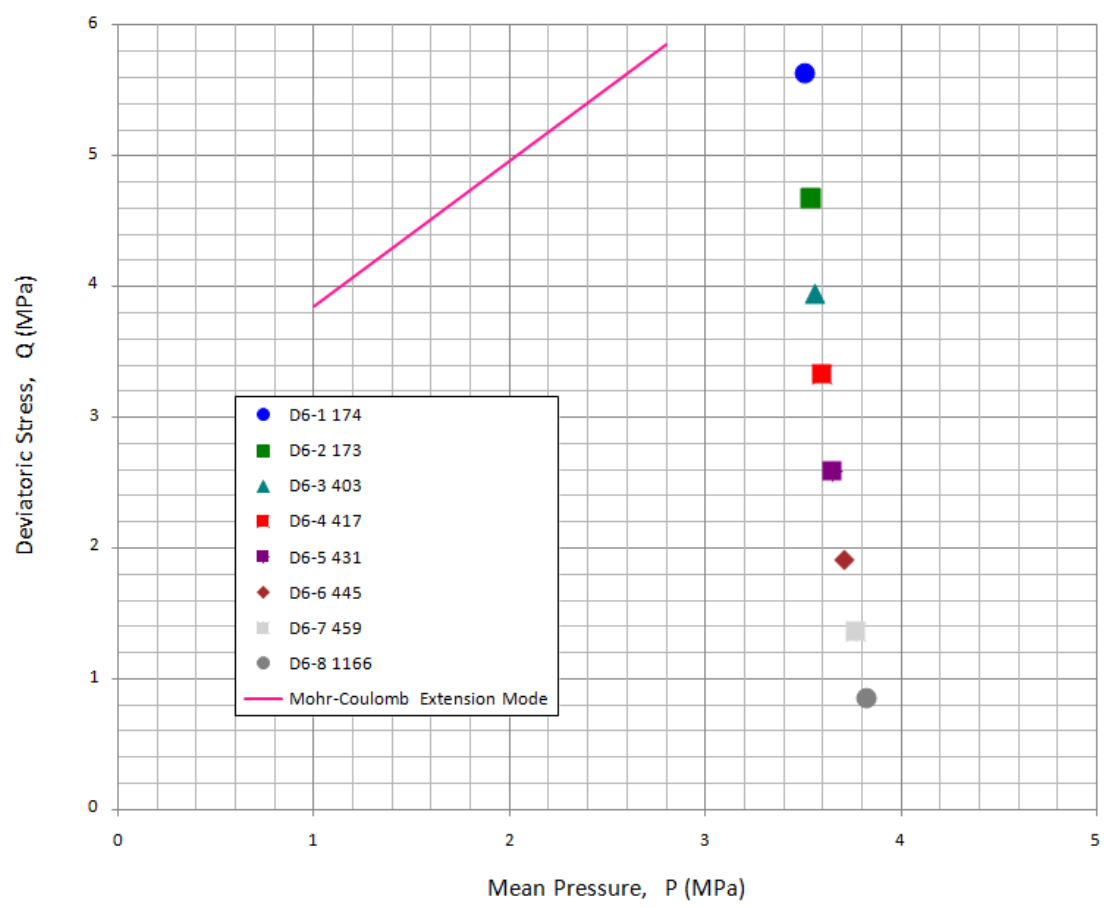

(b)

Figure 13. Stress state $(\mathrm{Ko}=1.0)$ : (a) Line C5; (b) Line D6. 
Stress State $:$ Ko = 2.0 Along Line C5

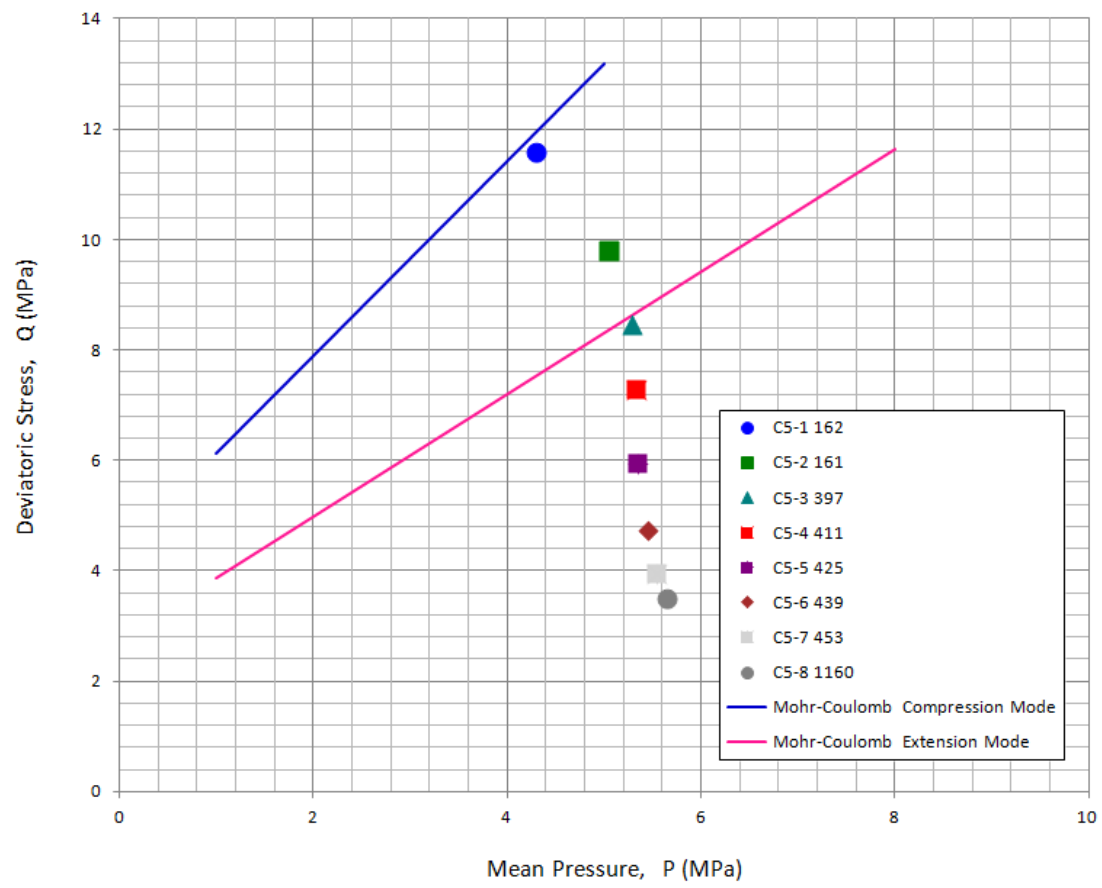

(a)

Stress State $: \mathrm{Ko}=2.0$ Along Line D6

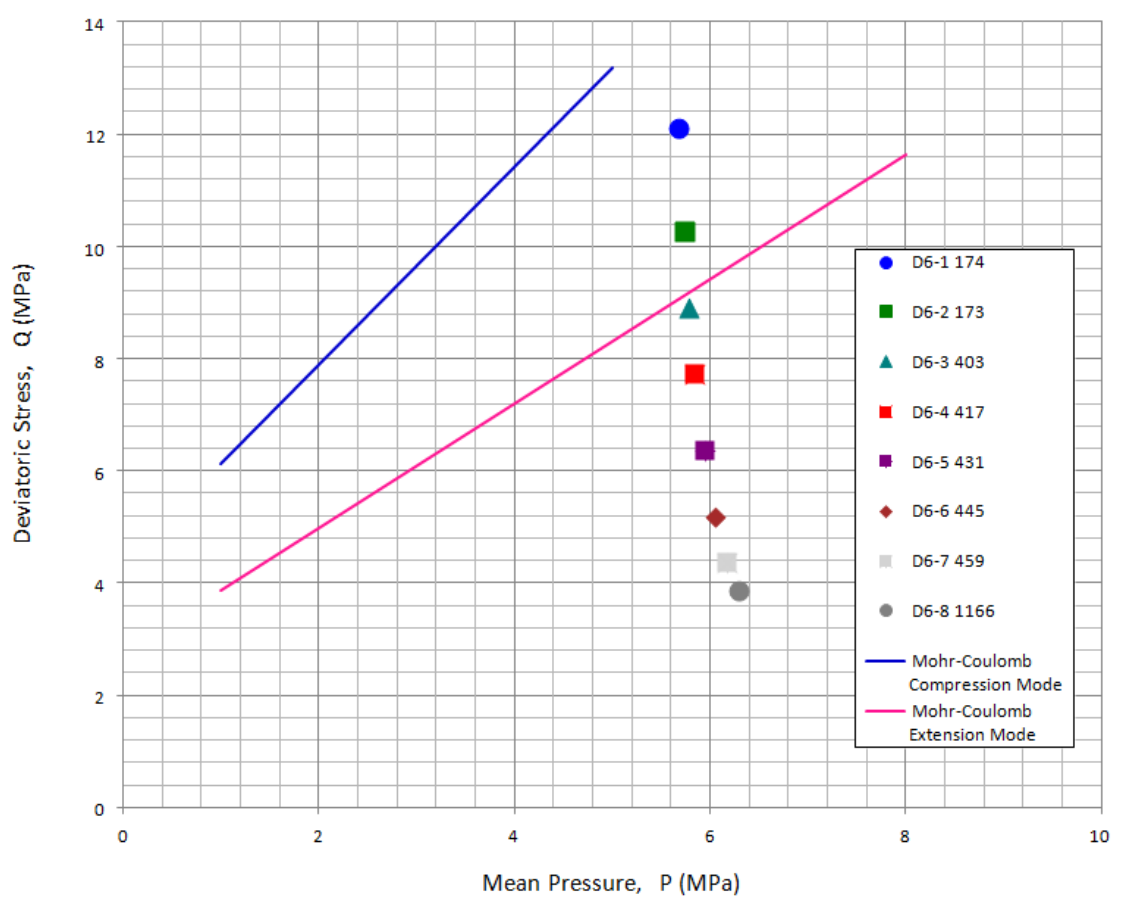

(b)

Figure 14. Stress state $(\mathrm{Ko}=2.0)$ : $(\mathbf{a})$ Line C5; (b) Line D6. 


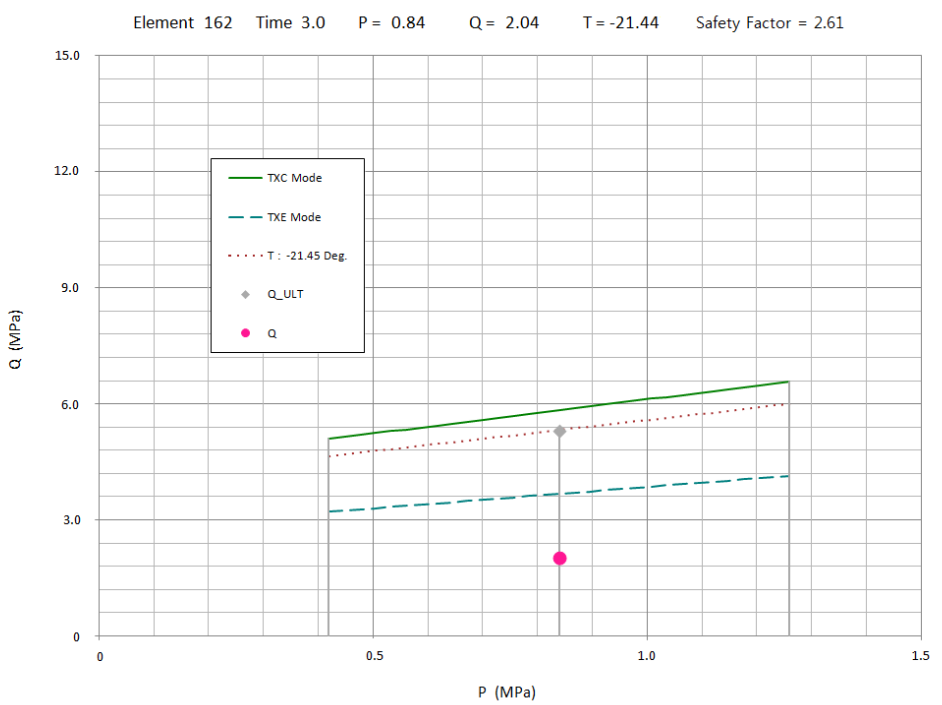

(a)

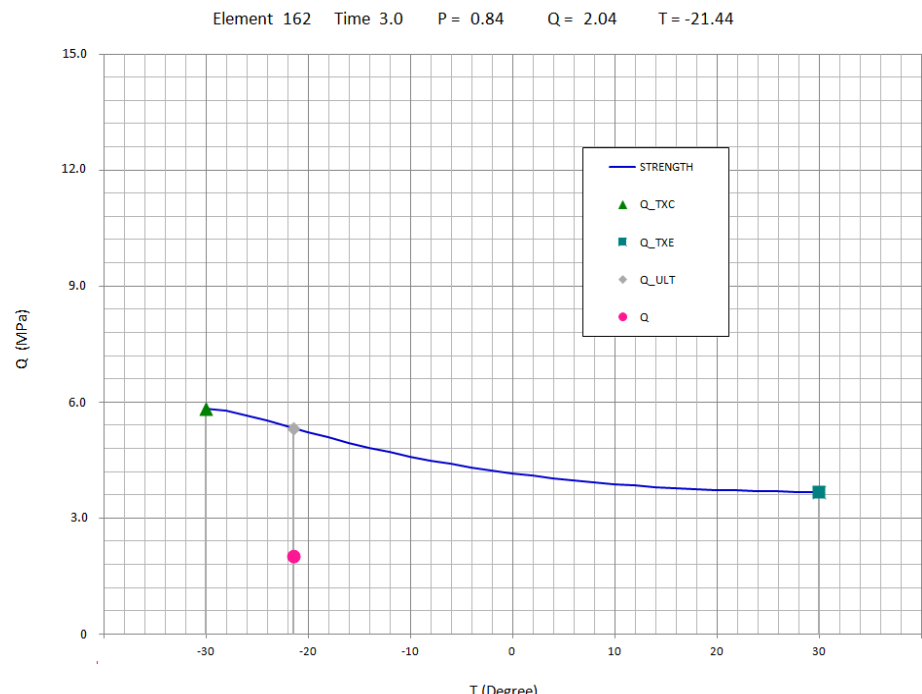

(b)

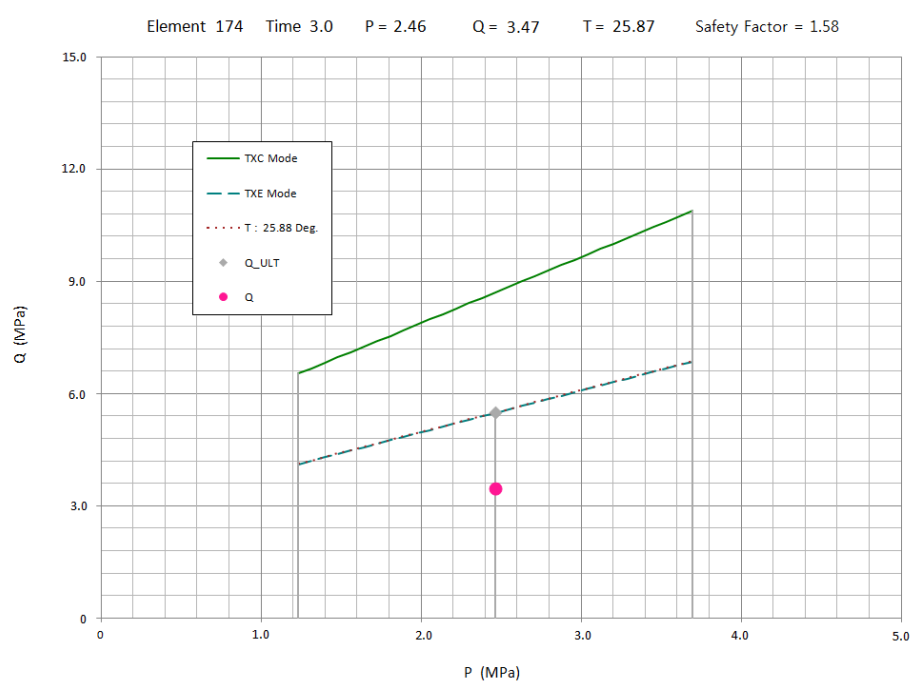

(c)

Figure 15. Cont. 


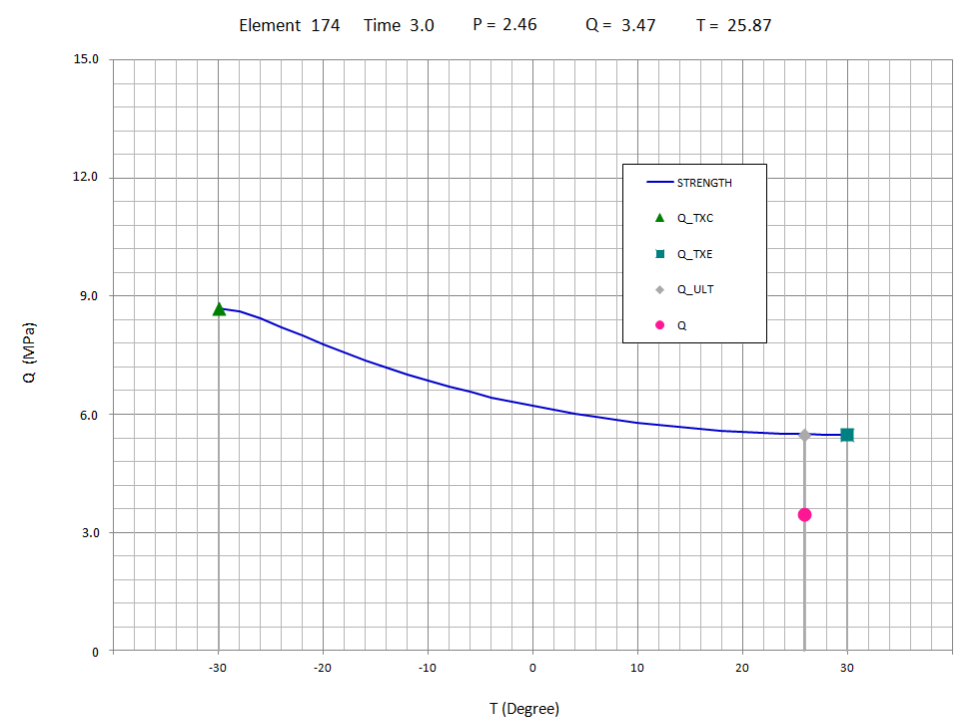

(d)

Figure 15. Stress state at the first element along lines $C 5$ and D6 $(K o=0.5)$ : (a) $p-q$ plot at Location C; (b) t-q plot at Location C; (c) p-q plot at Location D; (d) t-q plot at Location D.

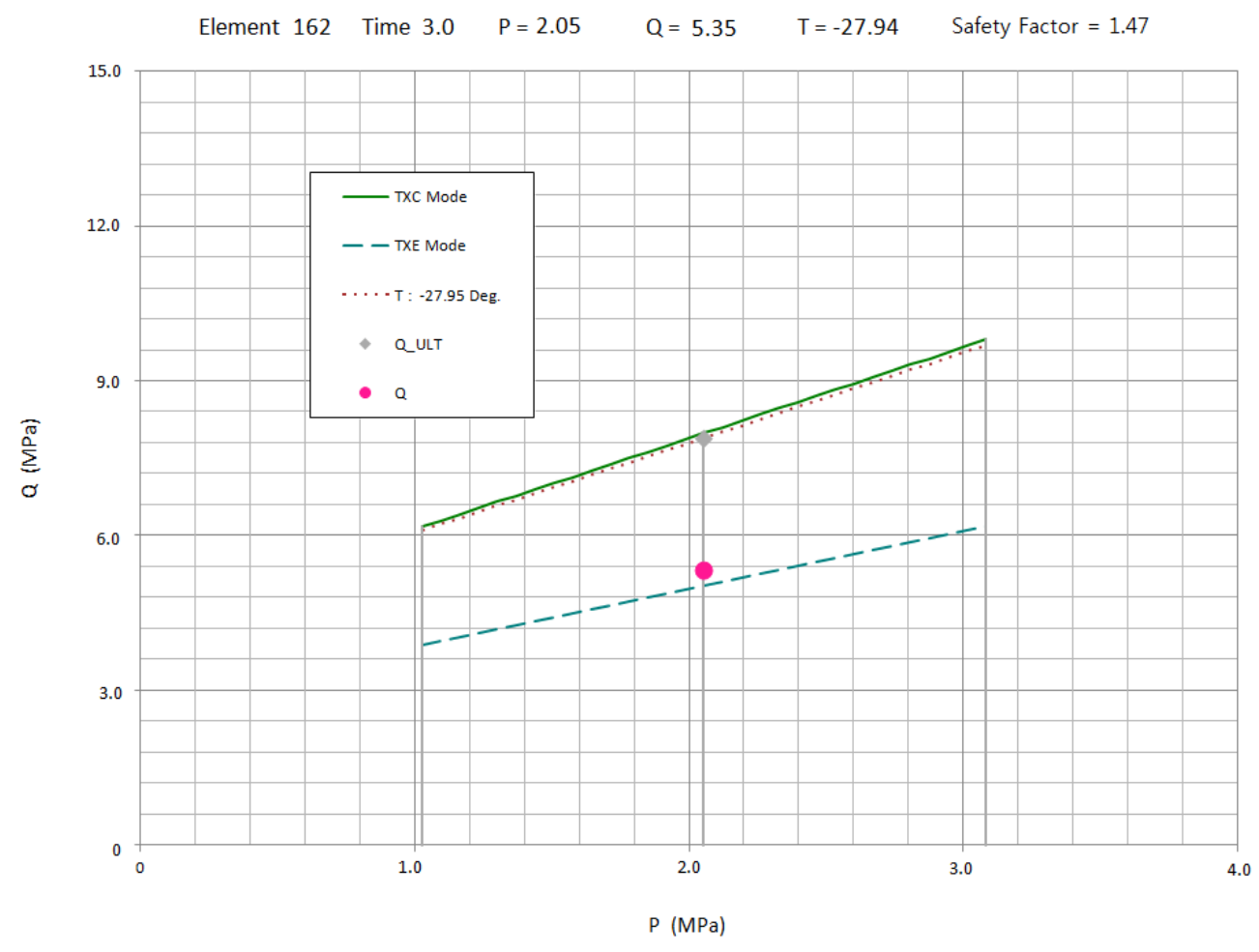

(a)

Figure 16. Cont. 


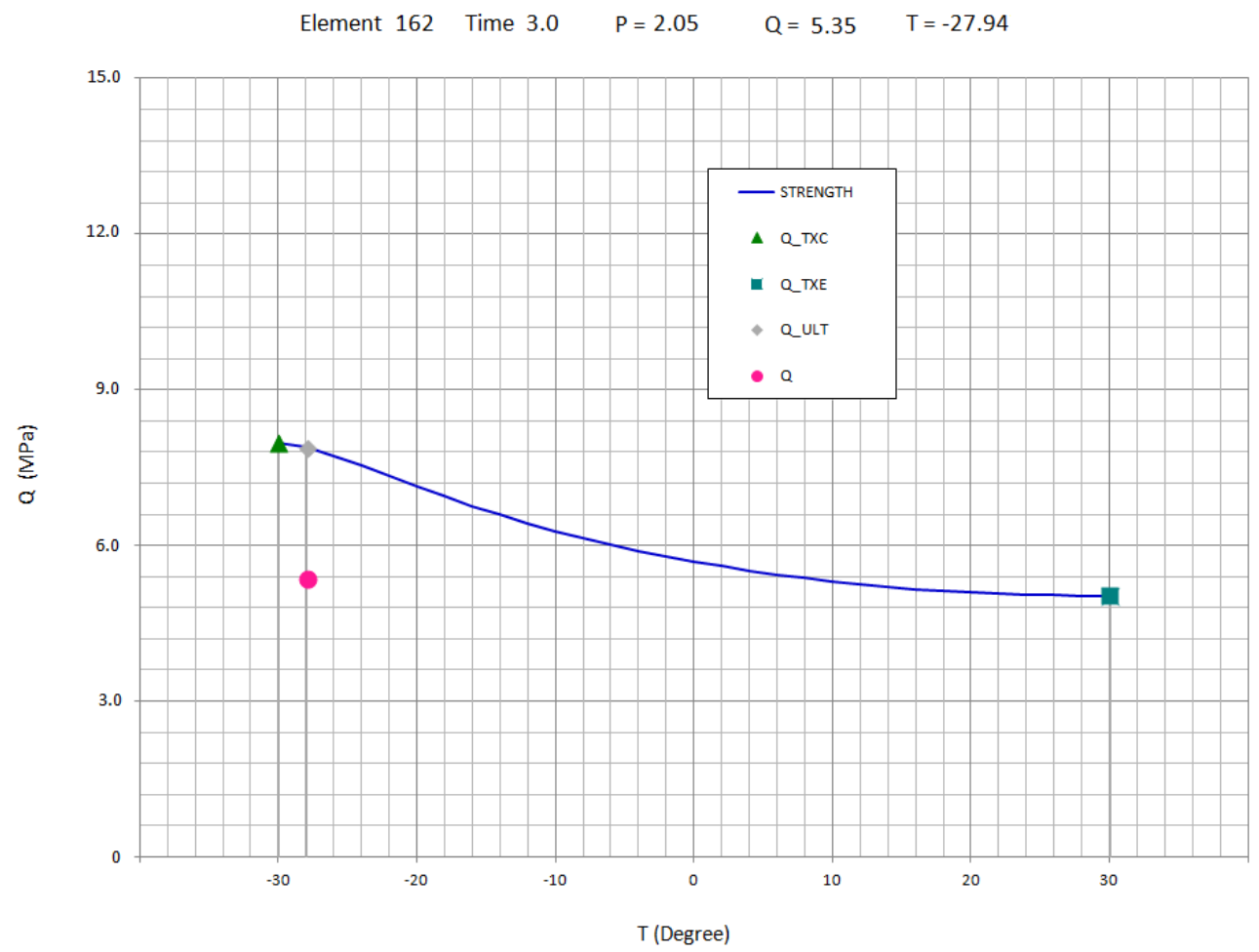

(b)

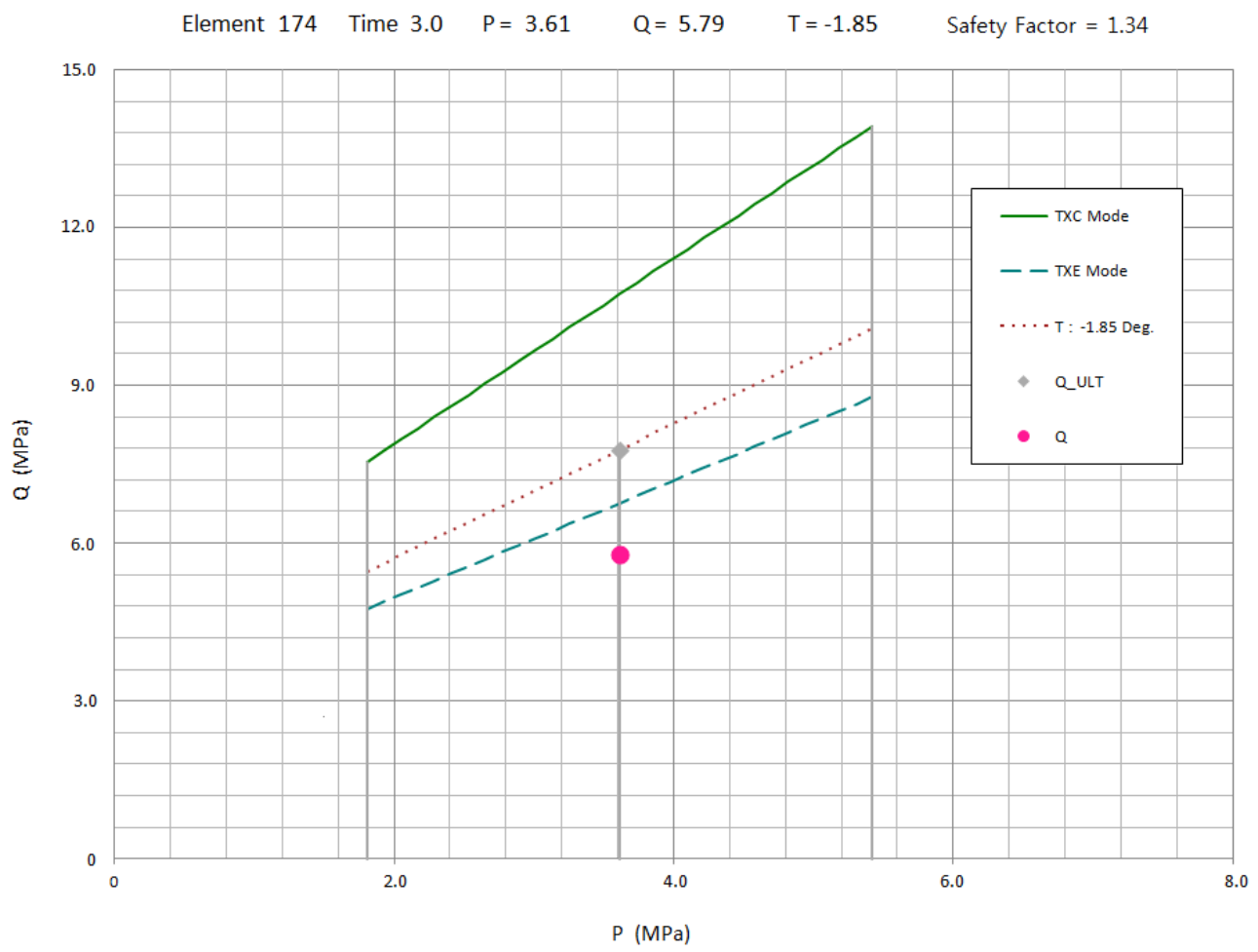

(c)

Figure 16. Cont. 


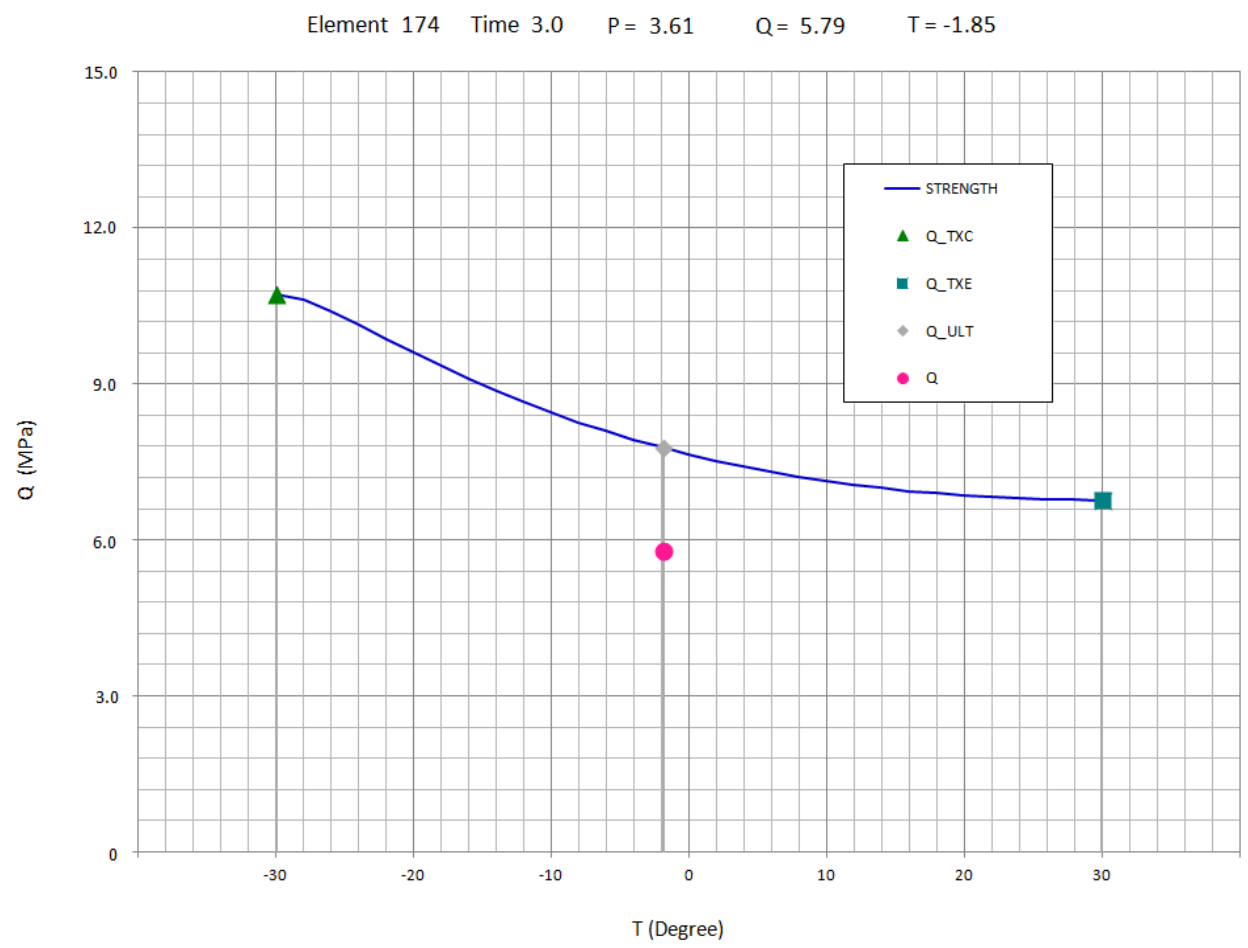

(d)

Figure 16. Stress state at the first element along lines C5 and D6 $(\mathrm{Ko}=1.0)$ : $(\mathbf{a}) \mathrm{p}-\mathrm{q}$ plot at Location C; (b) t-q plot at Location C; (c) p-q plot at Location D; (d) t-q plot at Location D.

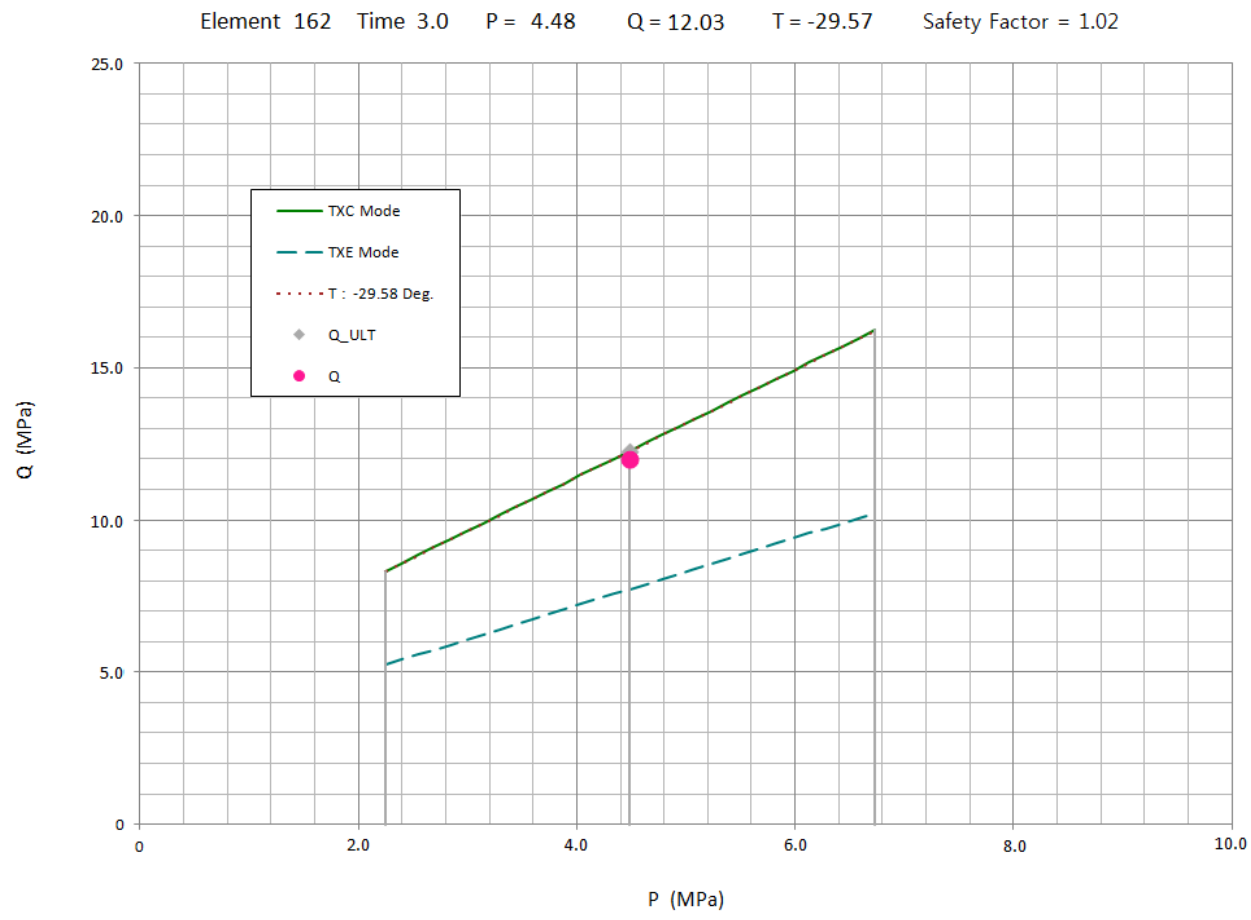

(a)

Figure 17. Cont. 


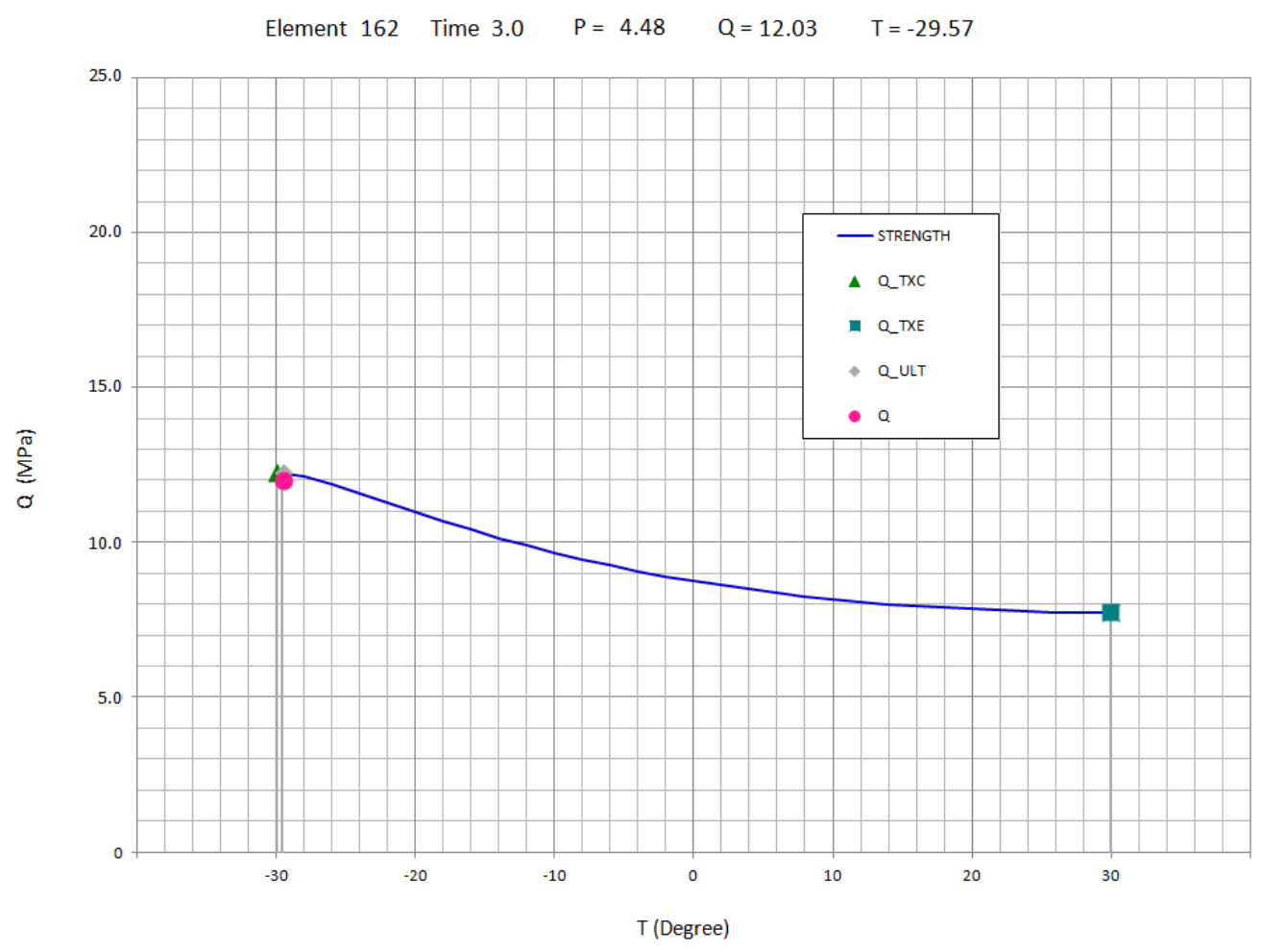

(b)

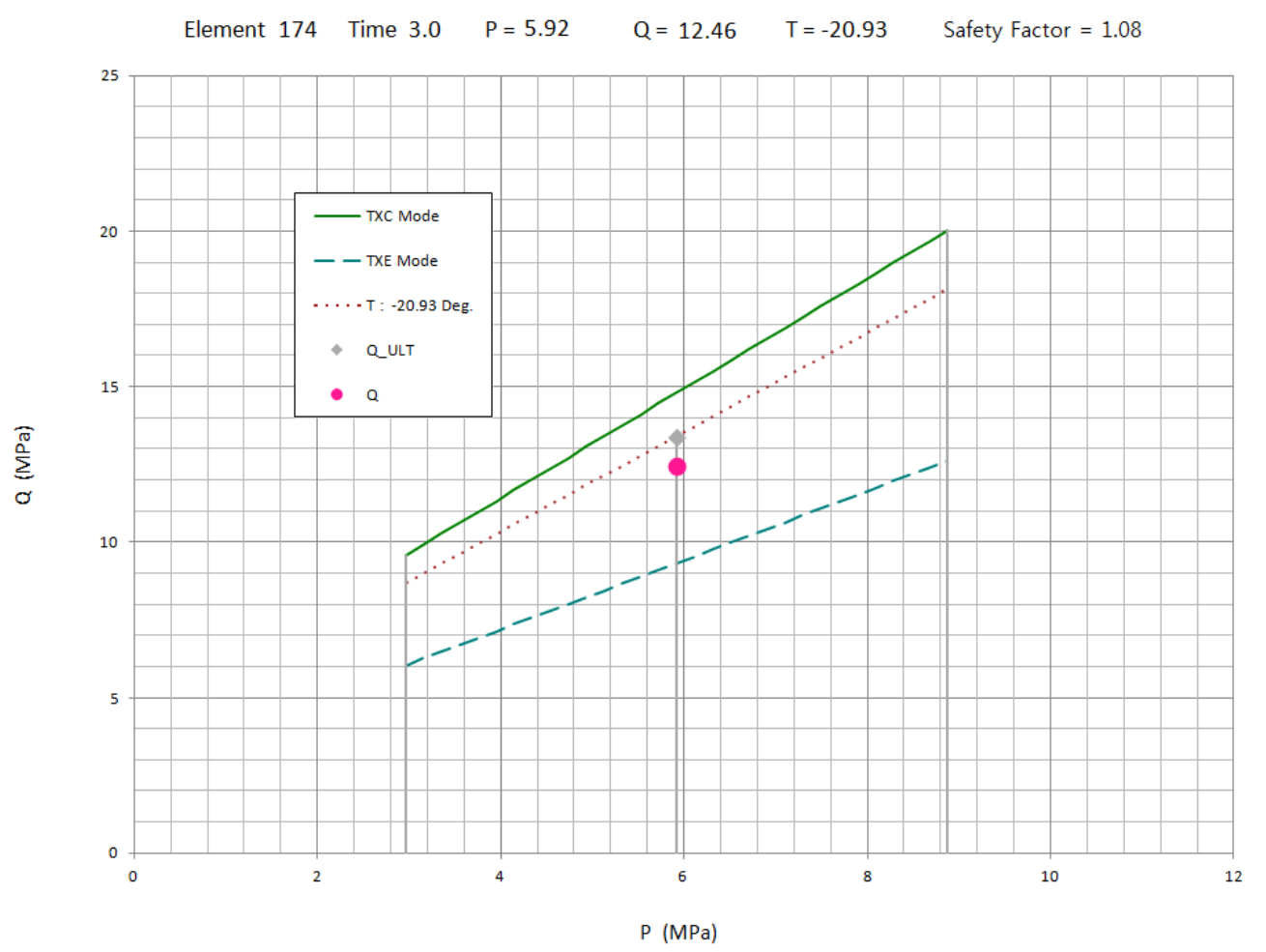

(c)

Figure 17. Cont. 


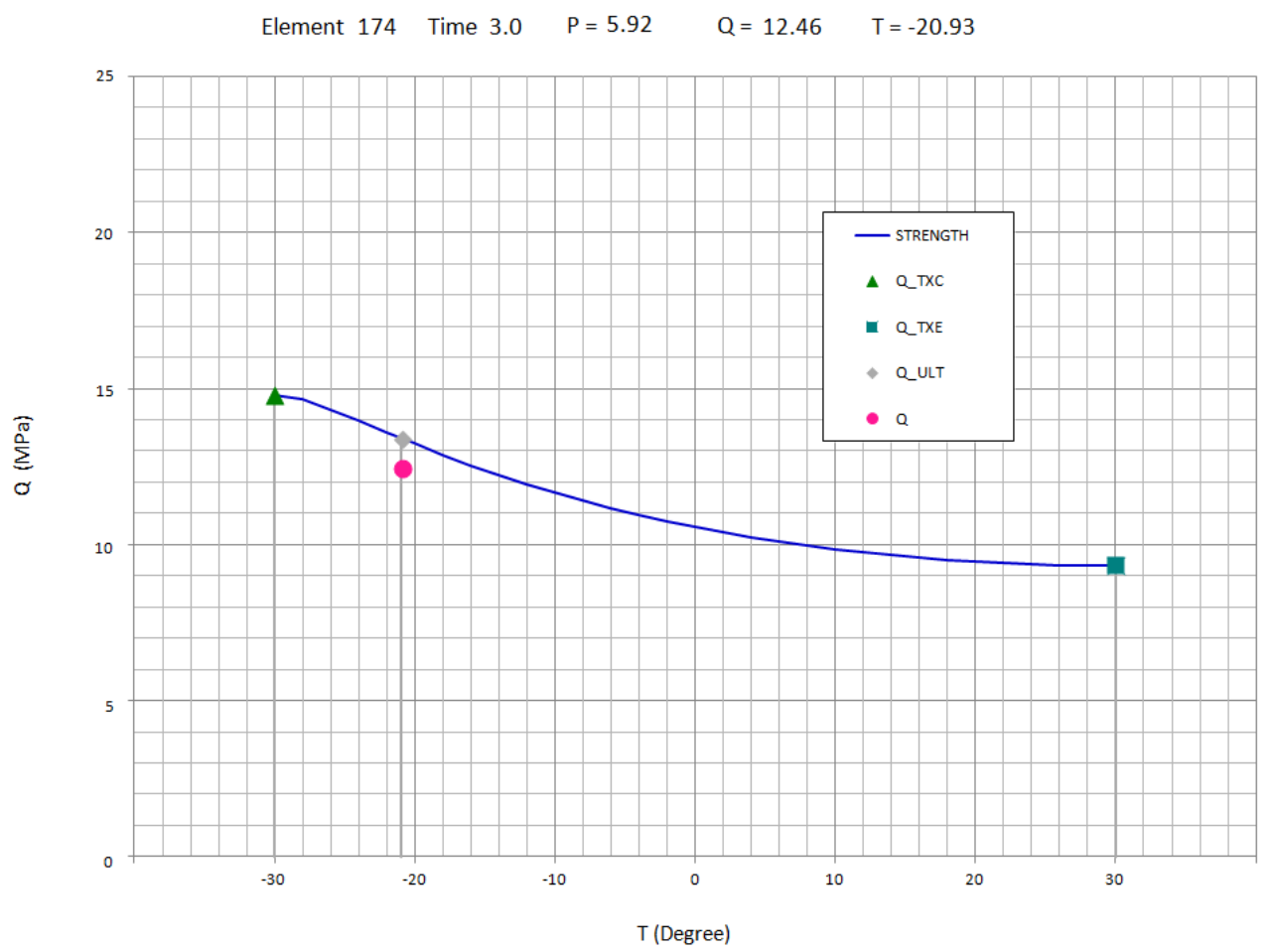

(d)

Figure 17. Stress state at the first element along lines C5 and D6 $(K o=2.0):(a) p-q$ plot at Location C; (b) t-q plot at Location C; (c) p-q plot at Location D; (d) t-q plot at Location D.

\subsection{Safety Factors}

In this section, the safety factor is presented using the stress value obtained through 2D axial symmetric analysis. The contours of safety factor distributions provide valuable information for evaluating the structural safety of the surrounding rock mass, which is the main supporting body of the underground silo.

The safety factor distributions according to change in the ratio of in situ horizontal stress to vertical stress (Ko) after single-step excavation of an underground silo are presented in Figures 18-20 for Ko values of 0.5, 1.0, and 2.0, respectively.

For $\mathrm{Ko}=0.5$, the zones with lower safety factors were more extended in the horizontal direction along the storage wall, with a minimum safety factor of 1.42 . The stress state in these zones, as shown in Figure 14d, were close to the triaxial extension mode where vertical and tangential stresses were contributing as major stresses and the horizontal stress as a minor stress. Overall, the surrounding rock mass was in a safe condition.

For $\mathrm{Ko}=1.0$, the zones with lower safety factors were more-or-less uniformly concentrated around the silo, with a minimum safety factor of 1.29. The stress states in these zones, as examined in Figure 15d, were close to the deviatoric pure shear mode where the major stress was tangential stress, the intermediate stress was vertical stress, and the minor stress was horizontal stress. Overall, the surrounding rock mass was in a safe condition.

For $\mathrm{Ko}=2.0$, the zones with lower safety factors were more widely spread around the silo compared to the cases for Ko values of 0.5 and 1.0. The stress states along the storage wall, as shown in Figure 16d, were closer to the triaxial compression mode. Overall, surrounding rock mass was in a safe condition except along the storage wall, where it almost reached ultimate strength with a minimum safety factor of 1.02. 


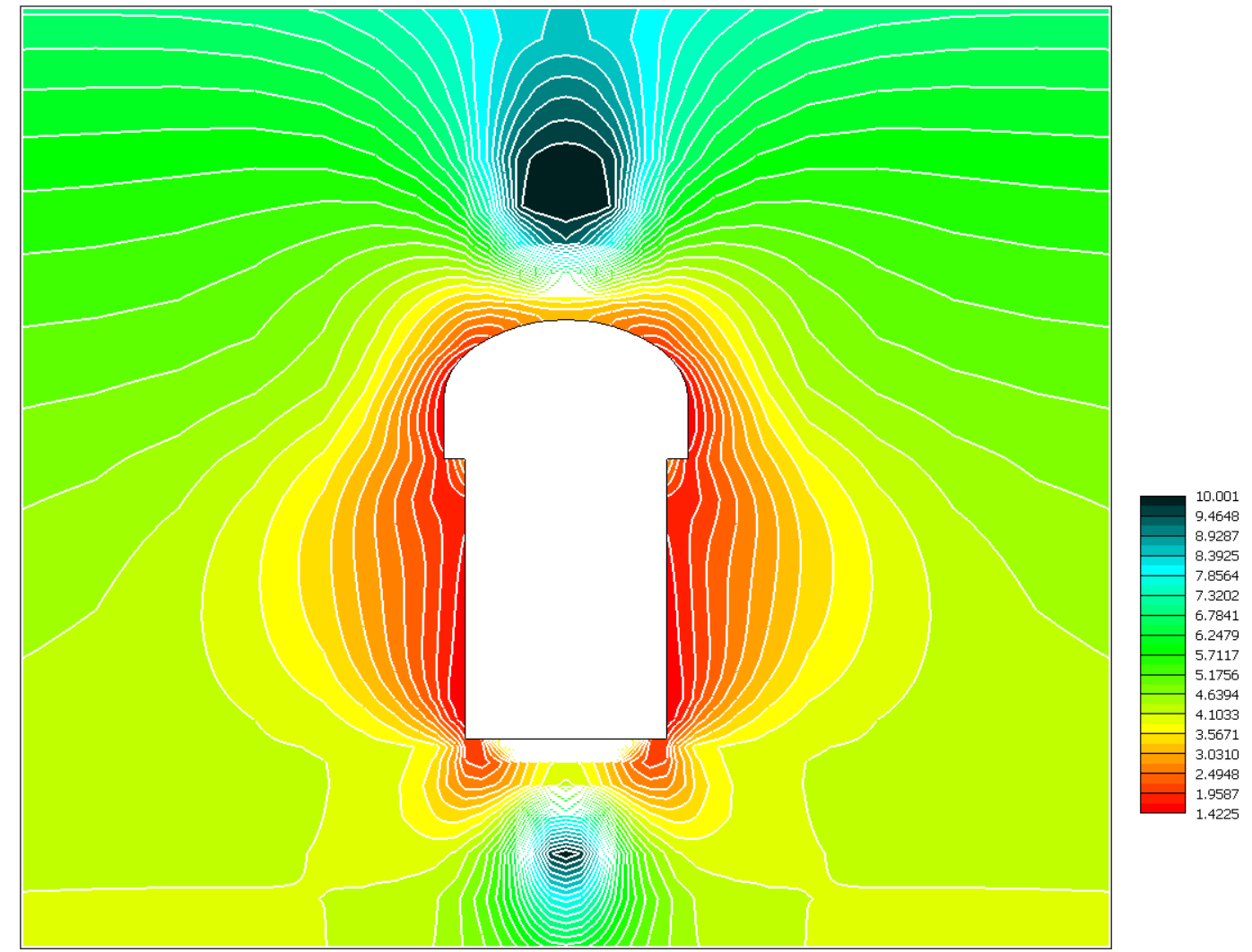

Figure 18. Safety factor distribution $(\mathrm{Ko}=0.5)$.

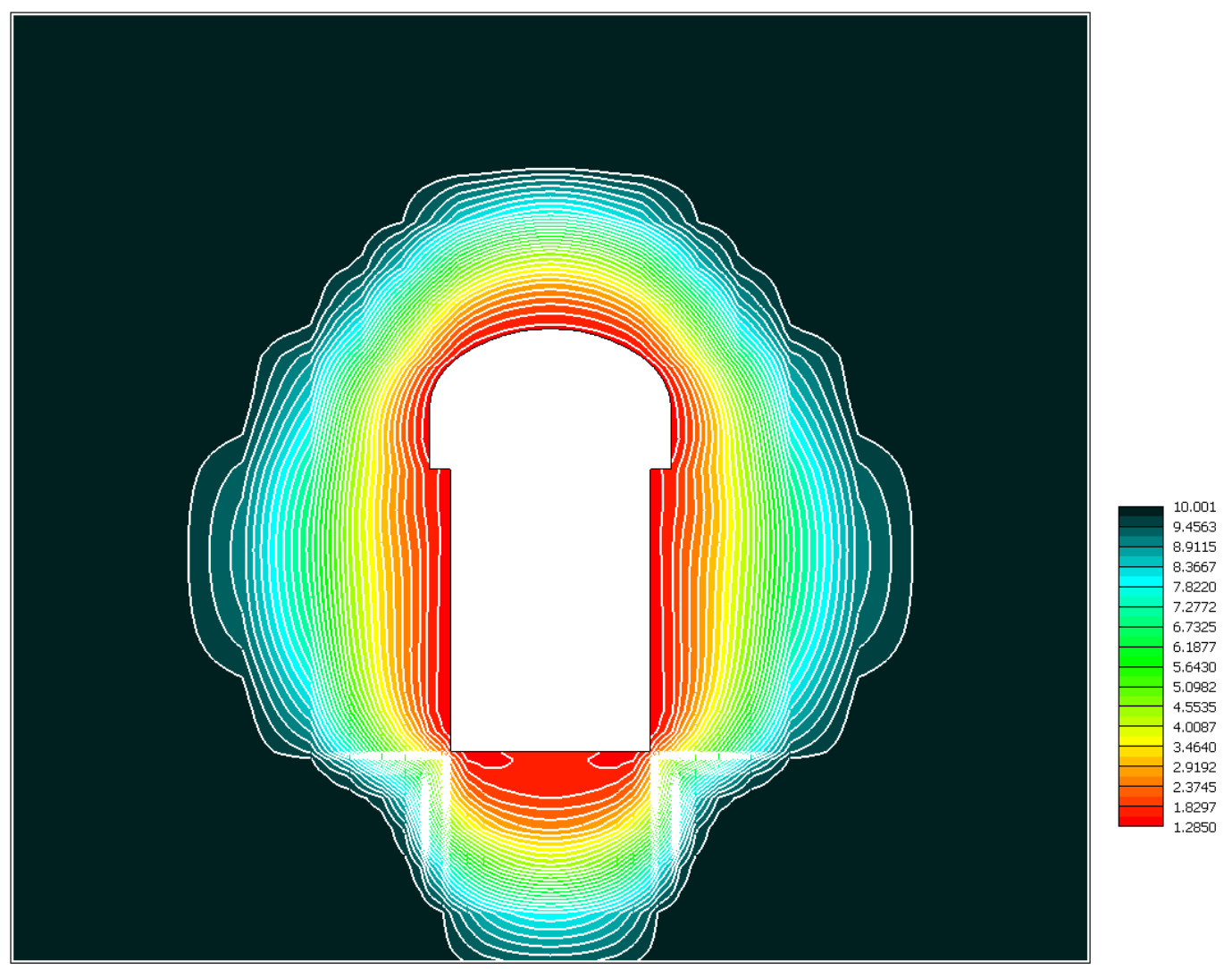

Figure 19. Safety factor distribution $\left(K_{0}=1.0\right)$. 


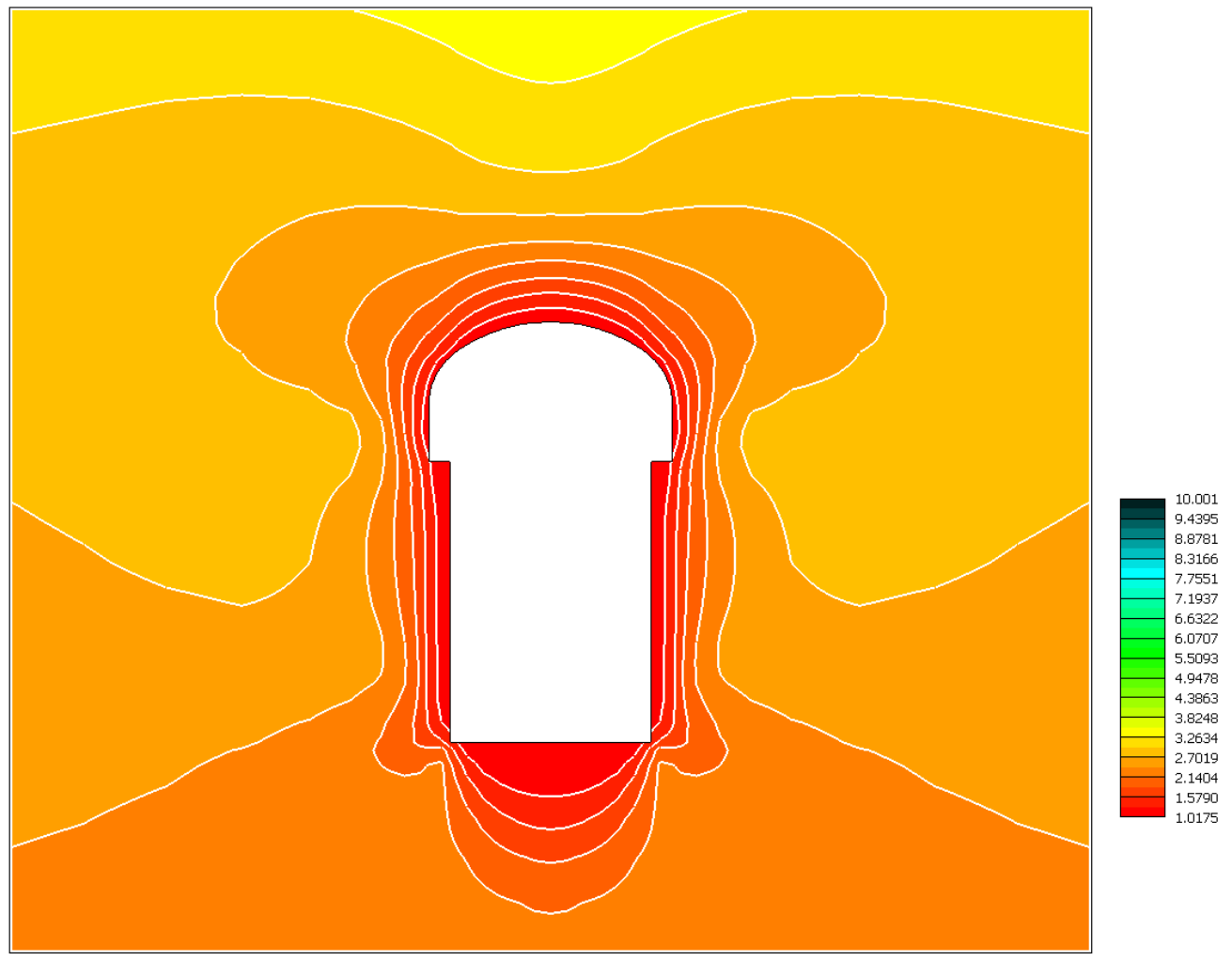

Figure 20. Safety factor distribution $(\mathrm{Ko}=2.0)$.

\section{Conclusions}

This article presented numerical parametric studies on the stress distribution in rocks around the underground silo for low- and intermediate-level radioactive waste disposal facilities in Korea. The 2D axial symmetric finite element model was used in this study, and a 3D finite element model was also used to verify the reliability of the 2D axial symmetric model. A finite element analysis of an analysis domain covering an underground silo and the surrounding rock mass was performed under three cases of differing ratios of in situ horizontal stress to vertical stress (Ko $=0.5,1.0$ and 2.0). Numerical results obtained through these analyses were presented and examined in detail for displacements, stresses, and safety factors associated with the excavation of an underground silo. To evaluate more accurately the stress state of the surrounding rock, a t-q plot showing the stress state in the octahedral plane was created, in addition to a $p-q$ stress plot. The safety factor was also presented, using the stress value obtained through numerical analysis.

The following conclusions arise from the numerical parametric study presented in this paper.

(1) The numerical results of the 3D analysis were almost identical in every case to those of the 2D axial symmetric analysis, confirming the reliability of the 2D finite element model.

(2) For the case of $\mathrm{Ko}=0.5$, the maximum displacement occurred in the vertical direction at the central point of the silo's bottom surface, since the in situ vertical stresses were twice as high as the in situ horizontal stresses. For the case of Ko $=2.0$, on the other hand, the maximum displacement occurred in the radial direction at the mid-point of the cylindrical wall, since the in situ horizontal stresses are twice higher than the in situ vertical stresses. For the case of $K o=1.0$, where the in-situ stresses were hydrostatic, the maximum vertical displacement at the central point of the silo's bottom surface was somewhat higher than the radial displacement at the mid-point of the cylindrical wall. 
(3) For Ko $=0.5$, all deviatoric stresses were somewhat below the lower-bound strength envelope in the triaxial extension mode. For $\mathrm{Ko}=1.0$, the deviatoric stress in the first element in line C5 reached the lower-bound strength in the triaxial extension mode. For $\mathrm{Ko}=2.0$, the deviatoric stresses in the first two elements in lines C5 and D6 were above the lower-bound strength envelope and the first element in line C5 almost reached the upper-bound shear strength in the triaxial compression mode.

(4) For $\mathrm{Ko}=0.5$, the stress state was somewhat close to the triaxial compression mode at Location $C$, but was closer to the triaxial extension mode at Location D. The safety factors were 2.61 and 1.58 at Location $C$ and $D$, respectively. For Ko $=1.0$, the stress state was very close to the triaxial compression mode at Location C, but was very close to the deviatoric pure shear mode at Location $D$, with a Lode angel of $-1.9^{\circ}$. The safety factors were 1.47 and 1.34 at Location $C$ and D, respectively. For Ko = 2.0, the stress state at Location $C$ was almost in the triaxial compression mode, reaching ultimate strength with a safety factor of 1.02. The stress state at Location D was also close to the triaxial compression mode, with a Lode angle of $-20.9^{\circ}$, reaching ultimate strength with a safety factor of 1.08. Thus, the silo's storage wall may be subjected to the onset of shear failure at these regions.

(5) It is better to compare the numerical results with in situ monitoring results. However, unfortunately, in situ monitoring results have not been reported anywhere. Any future data that is acquired should be compared with the results of this study.

Author Contributions: This study was initiated and designed by S.-H.K.; the numerical simulations, data analysis, and writing of the paper were undertaken by K.-J.K. All authors have read and agreed to the published version of the manuscript.

Funding: This work was partially supported by the "Radioactive Waste Management Program" of the Korea Institute of Energy Technology Evaluation and Planning (KETEP) and granted financial resources from the Ministry of Trade, Industry, and Energy, Republic of Korea (Project No. 20193210100040).

Institutional Review Board Statement: Not applicable.

Informed Consent Statement: Not applicable.

Data Availability Statement: Not applicable.

Conflicts of Interest: The authors declare no conflict of interest.

\section{Appendix A. Generalized Hoek and Brown Model Description}

\section{Appendix A.1. Failure Surface}

The failure surface in Equation (1) in Section 3 is written in terms of the alternate stress invariants ( $\mathrm{p}, \mathrm{q}$, and $\theta$ ) given by

$$
\begin{gathered}
\mathrm{p}=(1 / 3) \cdot \sigma_{i i} \\
S_{i j}=\sigma_{i j}-\mathrm{p} \cdot \delta_{i j} \\
J_{2}=(1 / 2) \cdot S_{i j} \cdot S_{i j} \\
J_{3}=(1 / 3) \cdot S_{i j} \cdot S_{j k} \cdot S_{k l} \\
\mathrm{q}=\sqrt{3 J_{2}} \\
\theta=1 / 3 \cdot \sin ^{-1}\left[(-27 / 2) \cdot\left(J_{3} / q^{3}\right)\right]
\end{gathered}
$$

where $\sigma_{i j}$ is the total stress tensor and $S_{i j}$ is the deviatoric stress tensor. 
Appendix A.2. Elastic Stress-Strain Relationship and Failure Surface

The incremental elastic constitutive law can be expressed in the following matrix form:

$$
\{d \sigma\}=\left[D^{e}\right]\left\{d \varepsilon^{e}\right\}
$$

where

$\{d \sigma\}$ stress increment

$\left[D^{e}\right]$ elastic stress - strain matrix

$\left\{d \varepsilon^{e}\right\}$ elastic strain increment

The expression for $R(\theta)$ in Equation (1) is given by

$$
\mathrm{R}(\theta)=\frac{x(\sqrt{3} \cos \theta+\sin \theta)+(2 k-1)\left[(2+\cos 2 \theta+\sqrt{3} \sin 2 \theta) x+5 k^{2}-4 k\right]^{\frac{1}{2}}}{\left[x(2+\cos 2 \theta+\sqrt{3} \sin 2 \theta)+(1-2 k)^{2}\right]}
$$

where

$(-\pi / 6 \leq \theta \leq \pi / 6)$

$x=\left(1-k^{2}\right)$

$k$ is the ratio of shear strength during triaxial extension to shear strength during triaxial compression under the same mean pressure

\begin{tabular}{|c|c|c|c|c|c|}
\hline Rock Quality & $\begin{array}{c}\text { Dolomite } \\
\text { Limestone } \\
\text { Marble }\end{array}$ & $\begin{array}{c}\text { Mudstone } \\
\text { Siltstone } \\
\text { Shale } \\
\text { Slate }\end{array}$ & $\begin{array}{l}\text { Sandstone } \\
\text { Quartzite }\end{array}$ & $\begin{array}{l}\text { Andesite } \\
\text { Dolerite } \\
\text { Rhyolite }\end{array}$ & $\begin{array}{c}\text { Amphibolite } \\
\text { Gabbro } \\
\text { Gneiss } \\
\text { Norite } \\
\text { Quartz-Diorite }\end{array}$ \\
\hline \multicolumn{6}{|l|}{ Intact } \\
\hline CSIR rating $=100$ & $\mathrm{~m}=7$ & 10.0 & 15.0 & 17.0 & 25.0 \\
\hline NGI rating $=150$ & $\mathrm{~s}=1$ & 1.0 & 1.0 & 1.0 & 1.0 \\
\hline \multicolumn{6}{|l|}{ Very Good Quality } \\
\hline CSIR rating $=85$ & 3.5 & 5.0 & 7.5 & 8.5 & 12.5 \\
\hline NGI rating $=100$ & 0.1 & 0.1 & 0.1 & 0.1 & 0.1 \\
\hline \multicolumn{6}{|l|}{ Good Quality } \\
\hline CSIR rating $=65$ & 0.7 & 1.0 & 1.5 & 1.7 & 2.5 \\
\hline NGI rating $=10$ & 0.004 & 0.004 & 0.004 & 0.004 & 0.004 \\
\hline \multicolumn{6}{|l|}{ Fair Quality } \\
\hline $\mathrm{CSIR}$ rating $=44$ & 0.14 & 0.20 & 0.3 & 0.34 & 0.5 \\
\hline NGI rating = 1 & 0.001 & 0.0001 & 0.0001 & 0.0001 & 0.0001 \\
\hline \multicolumn{6}{|l|}{ Poor Quality } \\
\hline CSIR rating $=23$ & 0.04 & 0.05 & 0.08 & 0.09 & 0.13 \\
\hline NGI rating $=0.1$ & 0.00001 & 0.00001 & 0.00001 & 0.00001 & 0.00001 \\
\hline \multicolumn{6}{|l|}{ Very Poor Quality } \\
\hline CSIR rating $=3$ & 0.007 & 0.01 & 0.015 & 0.017 & 0.025 \\
\hline NGI rating $=0.01$ & 0.0 & 0.0 & 0.1 & 0.0 & 0.0 \\
\hline
\end{tabular}

Table A1. Hoek and Brown Material Parameters (m, s). 
Appendix A.3. Flow Rule and Consistency Equation

A variable dilatancy potential function, $G$, is defined as

$$
\begin{gathered}
\frac{\partial G}{\partial p}=\left(\frac{\partial F}{\partial p}\right) r \\
\frac{\partial G}{\partial p}=\frac{\partial F}{\partial q} \\
\frac{\partial G}{\partial \theta}=\frac{\partial F}{\partial \theta}
\end{gathered}
$$

where $r$ is a dilatancy parameter $(0 \leq r \leq 1)$. No plastic volume change for $r=0$ and associated flow for $r=1$.

Thus, in general:

$$
\left\{d \varepsilon^{p}\right\}=d \lambda\{g\}
$$

where

$$
\{g\}=\left\{\frac{\partial G}{\partial \sigma}\right\}
$$

During yielding, the consistency equation forces the stress to move along the failure surface

$$
d \mathrm{~F}=\{\mathrm{a}\}^{T}\{d \sigma\}=0
$$

where

$$
\{\mathrm{a}\}=\left\{\frac{\partial F}{\partial \sigma}\right\}
$$

Appendix A.4. Incremental Elasto-Plastic Constitutive Law

Total strain is the sum of elastic and plastic strains and can be expressed as follows:

$$
\{d \varepsilon\}=\left\{d \varepsilon^{e}\right\}+\left\{d \varepsilon^{p}\right\}
$$

Substituting Equation (A8) into Equation (A2), we have:

$$
\{d \sigma\}=\left[D^{e}\right]\left(\{d \varepsilon\}-\left\{d \varepsilon^{p}\right\}\right)
$$

From the flow rule defined in Equation (A5), we can rewrite Equation (A9) as

$$
\{d \sigma\}=\left[D^{e}\right]\{d \varepsilon\}-d \lambda\left[D^{e}\right]\{g\}
$$

Substituting Equation (A10) into Equation (A6) and solving for $d \lambda$, we obtain

$$
d \lambda=\frac{\{\mathrm{a}\}^{T}\left[D^{e}\right]\{d \varepsilon\}}{\{\mathrm{a}\}^{T}\left[D^{e}\right]\{g\}}
$$

Back-substituting Equation (A11) into Equation (A10), the stress increment is directly related to the total strain increment as follows:

$$
\{d \sigma\}=\left[D^{e p}\right]\{d \varepsilon\}
$$


Table A2. Description of Rock Quality in Table A1.

\begin{tabular}{cc}
\hline Intact Rock Samples & $\begin{array}{c}\text { Laboratory size specimens } \\
\text { free from joints }\end{array}$ \\
\hline Very Good Quality Rock Mass & $\begin{array}{c}\text { Tightly interlocking undisturbed rock } \\
\text { with unweathered joints at } 1 \text { to } 3 \mathrm{~m}\end{array}$ \\
\hline Good Quality Rock Mass & $\begin{array}{c}\text { Fresh to slightly weathered rock, } \\
\text { slightly disturbed with joints at } 1 \text { to } 3 \mathrm{~m}\end{array}$ \\
\hline Fair Quality Rock Mass & $\begin{array}{c}\text { Several sets of moderately weathered } \\
\text { joints spaced at } 0.3 \text { to } 1 \mathrm{~m}\end{array}$ \\
\hline Poor Quality Rock Mass & $\begin{array}{c}\text { Numerous weathered joints } \\
\text { at } 30 \text { to } 500 \text { mm with sane gouge. } \\
\text { Clean compacted waste rock }\end{array}$ \\
\hline Very Poor Quality Rock Mass & $\begin{array}{c}\text { Numerous heavily weathered joints } \\
\text { spaced }<50 \text { m with gouge. } \\
\text { Waste rock with fines }\end{array}$ \\
\hline
\end{tabular}

where

$$
\left[D^{e p}\right]=\left[D^{e}\right]-\frac{\left[D^{e}\right]\{g\}\{\mathrm{a}\}^{T}\left[D^{e}\right]}{\{\mathrm{a}\}^{T}\left[D^{e}\right]\{g\}}
$$

Appendix A.5. Calculation of $\{a\}$

Differentiating the yield function with respect to $p, q$, and $\theta$, we have

$$
\begin{gathered}
\frac{\partial F}{\partial p}=-n(\alpha+\beta \cdot p)^{n-1} \cdot \beta \cdot R(\theta) \\
\frac{\partial F}{\partial q}=1 \\
\frac{\partial F}{\partial \theta}=-\left\{(\alpha+\beta \cdot p)^{n}+\kappa\right\} \cdot \frac{\partial R(\theta)}{\partial \theta}
\end{gathered}
$$

where

$$
\begin{gathered}
\frac{\partial R}{\partial \theta}=\left(1 / R_{D}\right) \cdot\left[\frac{\partial \mathrm{R}_{N}}{\partial \theta}-R(\theta) \cdot \frac{\partial \mathrm{R}_{D}}{\partial \theta}\right] \\
R_{N}=x \cdot(\sqrt{3} \cos \theta+\sin \theta)+(2 k-1)[(2+\cos 2 \theta+\sqrt{3} \sin 2 \theta) x \\
\left.+5 k^{2}-4 k\right]^{\frac{1}{2}} \\
R_{D}=x \cdot(2+\cos 2 \theta+\sqrt{3} \sin 2 \theta)+(1-2 k)^{2} \\
\frac{\partial R_{N}}{\partial \theta}=x \cdot(\cos \theta-\sqrt{3} \sin \theta)+\frac{x(2 k-1)(\sqrt{3} \cos 2 \theta-\sin 2 \theta)}{\left[x(2+\cos 2 \theta+\sqrt{3} \sin 2 \theta)+5 k^{2}-4 k\right]^{\frac{1}{2}}} \\
\frac{\partial R_{D}}{\partial \theta}=2 x \cdot(\sqrt{3} \cos 2 \theta-\sin 2 \theta)
\end{gathered}
$$

The derivative of the yield function with respect to stress can be expressed in general three-dimensional condition as

$$
\{\mathrm{a}\}=\frac{\partial F}{\partial p}\left\{\frac{\partial p}{\partial \sigma}\right\}+\frac{\partial F}{\partial q}\left\{\frac{\partial q}{\partial \sigma}\right\}+\frac{\partial F}{\partial \theta}\left\{\frac{\partial \theta}{\partial \sigma}\right\}
$$

where

$$
\begin{aligned}
& \left\{\frac{\partial p}{\partial \sigma}\right\}=\frac{1}{3}<111000>^{T} \\
& \left\{\frac{\partial \theta}{\partial \sigma}\right\}=\frac{g}{2 q^{3} \cos 3 \theta}\left(\frac{3 J_{3}}{q}\left\{\frac{\partial q}{\partial \sigma}\right\}-\left\{\frac{\partial J_{3}}{\partial \sigma}\right\}\right) \\
& \left\{\frac{\partial q}{\partial \sigma}\right\}=\frac{3}{2 q}<S_{x} S_{y} S_{z} 2 \sigma_{x y} 2 \sigma_{y z} 2 \sigma_{x z}>^{T}
\end{aligned}
$$




$$
\begin{aligned}
& \left\{\frac{\partial J_{3}}{\partial \sigma}\right\}=\left[\begin{array}{c}
S_{y} \cdot S_{z}-\sigma_{y z}^{2}+(1 / 9) \cdot q^{2} \\
S_{x} \cdot S_{z}-\sigma_{x z}^{2}+(1 / 9) \cdot q^{2} \\
S_{x} \cdot S_{y}-\sigma_{x y}^{2}+(1 / 9) \cdot q^{2} \\
2\left(-S_{z} \cdot \sigma_{x y}+\sigma_{y z} \cdot \sigma_{x z}\right) \\
2\left(-S_{x} \cdot \sigma_{y z}+\sigma_{x z} \cdot \sigma_{x y}\right) \\
2\left(-S_{y} \cdot \sigma_{x z}+\sigma_{x y} \cdot \sigma_{y z}\right)
\end{array}\right] \\
& \{\sigma\}^{T}=<\sigma_{x} \sigma_{y} \sigma_{z} \sigma_{x y} \sigma_{y z} \sigma_{x z}> \\
& \{\varepsilon\}^{T}=<\varepsilon_{x} \varepsilon_{y} \varepsilon_{z} \gamma_{x y} \gamma_{y z} \gamma_{x z}> \\
& \gamma_{x y}=2 \varepsilon_{x y} \gamma_{y z}=2 \varepsilon_{y z} \gamma_{x z}=2 \varepsilon_{x z}
\end{aligned}
$$

\section{References}

1. Park, J.B.; Jung, H.R.; Lee, E.Y.; Kim, C.L.; Kim, G.Y.; Kim, K.S.; Koh, Y.K.; Park, K.W.; Cheong, J.H.; Jeong, C.W.; et al. Wolsong low- and intermediate-level radioactive waste disposal center: Progress and challenges. Nucl. Eng. Technol. 2009, 41, 477-492. [CrossRef]

2. KORAD. Earth $\mathcal{E} U$ s; Korea Radioactive Waste Agency: Gyeongju, Korea, 2018.

3. Korean repository realised. Nuclear Engineering International. Available online: https://www.neimagazine.com/features/ featurekorean-repository-realised-4323899 (accessed on 22 July 2014).

4. First waste disposal at Korean repository. World Nuclear News. Available online: https:/ /www.world-nuclear-news.org/WRFirst-waste-disposal-at-Korean-repository-1407154.html (accessed on 14 July 2015).

5. Malvić, T.; Pimenta Dinis, M.A.; Velić, J.; Sremac, J.; Ivšinović, J.; Bošnjak, M.; Barudžija, U.; Veinović, Ž.; Sousa, H.F.P.e. Geological risk caluculation through probability of success (PoS), applied to radioactive waste disposal in deep wells: A conceptual study in the pre-neogene basement in the Nothern Croatia. Processes 2020, 8, 755. [CrossRef]

6. Barešić, J.; Parlov, J.; Kovač, Z.; Sironić, A. Use of nuclear power plant released tritium as a groundwater tracer. Rud.-Geol.-Naft. Zb. 2019, 35, 25-35. [CrossRef]

7. Mališ, T.; Milling, A.; Jaguljnjak-Lazarević, A. Preliminary design of potential storage facility for low and intermediate level radioactive waste. Rud.-Geol.-Naft. Zb. 2018, 33, 27-36. [CrossRef]

8. Veinović, Ž.; Uroić, G.; Domitrović, D.; Kegel, L. Thermo-hydro-mechanical effects on host rock for a generic spent nuclear fuel repository. Rud.-Geol.-Naft. Zb. 2019, 35, 65-80. [CrossRef]

9. Bang, J.H.; Park, J.H.; Jung, K.I. Development of two-dimensional near-field integrated performance assessment model for near-surface LILW disposal. J. Nucl. Fuel Cycle Waste Technol. 2014, 12, 315-334. [CrossRef]

10. Jung, K.I.; Kim, J.H.; Kwon, M.J.; Jeong, M.S.; Hong, S.W.; Park, J.B. Comprehensive development plans for the low- and intermediate-level radioactive waste disposal facility in Korea and preliminary safety assessment. J. Nucl. Fuel Cycle Waste Technol. 2016, 14, 385-410. [CrossRef]

11. Kim, K.H.; Ree, J.H.; Kim, Y.H.; Kim, S.S.; Kang, S.Y.; Seo, W.S. Assessing whether the 2017 Mw 5.4 Pohang earthquake in South Korea was an induced event. Science 2018, 360, 1007-1009. [CrossRef]

12. Jin, K.; Lee, J.; Lee, K.; Kyung, J.B.; Kim, Y.S. Earthquake damage and related factors associated with the $2016 \mathrm{ML}=5.8 \mathrm{Gyeongju}$ earthquake, southeast Korea. Geosci. J. 2020, 24, 141-157. [CrossRef]

13. Kim, M.K.; Choi, I.K.; Jeong, J. Development of a seismic risk assessment system for low and intermediate level radioactive waste repository-Current status of year 1 research. In Proceedings of the WM2011 Conference, Phoenix, AZ, USA, 27 February-3 March 2011.

14. Byen, H.; Jeong, G.Y.; Park, J. Structural stability analysis of waste packages containing low- and intermediate-level radioactive waste in a silo-type repository. Nucl. Eng. Technol. 2021, 53, 1524-1533. [CrossRef]

15. Cho, H.; Cheong, J.; Lim, D.; Hamm, S. Quantification of heterogeneous background fractures in bedrocks of Gyeongju LILW disposal site. J. Eng. Geol. 2017, 27, 463-474. (In Korean) [CrossRef]

16. Park, J.B. Development of safety case for the Wolsong L\&ILW disposal facility in Korea: Geological event. In Proceedings of the 16th Meeting of the Integration Group for the Safety Case, NEA/France, Paris, France, 7-9 October 2014.

17. Shin, Y.; Lee, J. The status and experiences of LILW disposal facilities construction. J. Korean Soc. Miner. Energy Resour. Eng. 2017, 54, 389-396. (In Korean) [CrossRef]

18. Carranza-Torres, C. Elasto-plastic solution of tunnel problems using the generalized form of the Hoek-Brown failure criterion. Int J. Rock Mech. Min. Sci. 2004, 41, 629-639. [CrossRef]

19. Zhu, H.; Zhang, Q.; Huang, B.; Zhang, L. A constitutive model based on the modified generalized three-dimensional Hoek-Brown strength criterion. Int. J. Rock Mech. Min. Sci. 2017, 98, 78-87. [CrossRef]

20. Wei, Y.; Jiaxin, L.; Zonghong, L.; Wei, W.; Xiaoyun, S. A strength reduction method based on the Generalized Hoek-Brown (GHB) criterion for rock slope stability analysis. Comput. Geotech. 2020, 117, 103240. [CrossRef]

21. Hoek, E.; Brown, E.T. Empirical strength criterion for rock masses. J. Gectech. Eng. Div. ASCE 1980, 106, 1013-1035. [CrossRef]

22. Hoek, E.; Brown, E.T. Underground Excavations in Rock; The Institution of Mining and Metallurgy: London, UK, 1984.

23. Lester, A.M.; Sloan, S.W. A smooth hyperbolic approximation to the Generalised classical yield function, including a true inner rounding of the Mohr-Coulomb deviatoric section. Comput. Geotech. 2018, 104, 331-357. [CrossRef] 
24. Kim, K.J.; Piepenburg, D.D.; Merkle, D.H. Influence of the Intermediate Principal Stress on Rock Tunnel Behavior; Report No. DNA-TR-86-52; Defense Nuclear Agency: Fort Belvoir, VA, USA, 1987.

25. Eberhardt, E. The Hoek-Brown failure criterion. Rock Mech. Rock Eng. 2012, 43, 981-988. [CrossRef]

26. Ledesma, O.; Mendive, I.G.; Sfriso, A. Factor of safety by the strength-reduction technique applied to the Hoek-Brown model. In Proceedings of the XXII Congress on Numerical Methods and their Applications, Córdoba, Argentina, 8-11 November 2016.

27. Pande, G.N. Numerical Methods Rock Mechanics; John Wiley \& Sons: Hoboken, NJ, USA, 1990.

28. Zienkiewicz, O.C.; Chan, A.H.; Pastor, M.; Schrefler, B.A.; Shiomi, T. Computational Geomechanics with Special Reference to Earthquake Engineering; John Wiley \& Sons: New York, NY, USA, 1999.

29. Potts, D.M.; Zdravkovic, L. Finite Element Analysis in Geotechnical Engineering Application; Thomas Telford: London, UK, 2001.

30. Mroueh, H.; Shahrour, I. Three-dimensional finite element analysis of the interaction between tunneling and pile foundations. Int. J. Numer Anal. Met. 2002, 26, 217-230. [CrossRef]

31. Li, Y.; Sun, R.G. Stability analysis of tunnel surrounding rock and shotcrete lining and rock bolts based on strength reduction finite element method. Appl. Mech Mater. 2011, 90, 1936-1941. [CrossRef]

32. Nawel, B.; Salah, M. Numerical modeling of two parallel tunnels interaction using three-dimensional finite elements method. Geomech. Eng. 2015, 9, 775-791. [CrossRef]

33. Khaledi, K.; Mahmoudi, E.; Datcheva, M.; Schanz, T. Stability and serviceability of underground energy storage caverns in rock salt subjected to mechanical cyclic loading. Int. J. Rock Mech. Min. Sci. 2016, 86, 115-131. [CrossRef]

34. Coppola, T.; Cortese, L.; Folgarait, P. The effect of stress invariants on ductile fracture limit in steels. Eng. Fract. Mech. 2009, 76, 1288-1302. [CrossRef]

35. Jiang, H.; Yang, Y. A Three-dimensional Hoek-Brown failure criterion based on an elliptical Lode dependence. Int. J. Numer. Anal. Met. 2020, 44, 2395-2411. [CrossRef] 